\title{
DERIVATIVE SUIT SETTLEMENTS: IN SEARCH OF A NEW LODESTAR
}

\section{INTRODUCTION}

The Supreme Court has characterized a stockholder's right to sue on behalf of the corporation as "the chief regulator of corporate management." Although a myriad of issues surrounds shareholder derivative litigation, ${ }^{2}$ the scope of this note is restricted to certain problems encountered in the settlement of such actions. Rule 23.1 of the Federal Rules of Civil Procedure (hereinafter Rule 23.1) governs the settlement of shareholder derivative actions in federal courts. Rule 23.1 provides in relevant part:

In a derivative action brought by one or more shareholders or members to enforce a right of a corporation or of an unincorporated association, . . . [t]he action shall not be dismissed or compromised without the approval of the court, and notice of the proposed dismissal or compromise shall be given to shareholders or members in such manner as the court directs.

Numerous states now have statutes that either duplicate Rule 23.1 or contain substantially similar requirements. ${ }^{3}$

After reviewing several introductory matters, this note discusses four perplexing issues necessarily raised by the settlement of shareholder derivative litigation:

(1) The potential conflicts of interest between the plaintiff and his attorney;

(2) The appropriate criteria courts should consider in deciding whether to approve a settlement;

(3) The role of objecting shareholders in the settlement process; and

(4) The method for computing counsel fee awards.

Copyright $\subset 1985$ by Law and Contemporary Problems

1. Cohen v. Beneficial Indus. Loan Corp., 337 U.S. 541,548 (1949).

2. For a discussion of other issues surrounding shareholder derivative litigation, such as standing, state security for expenses statutes, the adequacy of counsel, and the right to a jury trial, see H. Henn \& J. Alexander, Laws of Corporations 1019 (3d ed. 1983). For a discussion of the history and purpose of FEd. R. Civ. P. 23.1, see 3B J. Moore \& J. Kennedy, Moore's Federal Practice 1 23.1.01 (2d ed. 1984); 7A C. Wright \& A. Miller, Federal Practice and Procedure $\$ 1821$ (1972).

3. See, e.g., Ala. R. Civ. P. 23.1; Alaska R. Crv. P. 23.1; Ariz. R. Civ. P. 23.1; Ark. R. Civ. P. 23.1; Colo. R. Civ. P. 23.1; Del. Ch. Ct. R. 23.1; Fla. Stat. Ann. § 607.147 (West 1984); Ga. Code Ann. § 14-2-123(d)(1982); Idaho R. Civ. P. 23(f); Ind. Trial Rule 23.1; Kan. R. Civ. P. 60-223(e); Ky. Rev. Stat. Ann. § 271 A.245 (Baldwin 1984); Mass. R. Civ. P. 23.1; Minn. R. Civ. P. 23.06; Nev. R. Civ. P. 23.1; N.Y. Bus. Corp. Law $\$ 626$ (d) (McKinney 1984); Utah R. CIV. P. 23.1. 


\section{A. The History and Purpose of Rule 23.1}

Notice to the shareholders and court approval of a proposed dismissal or settlement of a shareholder derivative suit have been required since the adoption of Rule 23(c) in 1938.4 It was not until 1966, however, that Congress enacted Rules 23(e) ${ }^{5}$ and .23.1. Although Rules 23(e) and 23.1 plainly preserved the notice and court approval requirements found in Rule 23(c), they established separate treatment for class actions and derivative suits. ${ }^{6}$ The clear differentiation of class actions from shareholder derivative actions was a response to the "distinctive aspects" of derivative litigation.7

An action may be said to be representative when it is based upon a primary or personal right belonging to the plaintiff-stockholder and those of his class. It is derivative when the action is based upon a primary right of the corporation but which is asserted on its behalf by the stockholder because of the corporation's failure, deliberate or otherwise, to act upon the primary right. ${ }^{8}$

Despite these significant differences, pre-1966 decisions involving derivative actions under Rule 23(c) are still considered authoritative precedent. ${ }^{9}$ In addition, the common ancestry of Rules $23(\mathrm{e})$ and 23.1 renders cases involving the dismissal or settlement of class actions relevant by analogy to derivative suits. ${ }^{10}$

At least three major reasons exist for requiring notice and court approval of a proposed dismissal or settlement of a derivative action. First, these prophylactic procedures help discourage "private settlements" 11 whereby a

4. 7A C. Wright \& A. Miller, supra note 2, § 1797, at 226, § 1839, at 427; Haudek, The Settlement and Dismissal of Stockholders'Actions-Part I, 22 Sw. L.J. 767 (1968).

5. "A class action shall not be dismissed or compromised without the approval of the court, and notice of the proposed dismissal or compromise shall be given to all members of the class in such manner as the court directs." FED. R. CIV. P. 23(e).

6. 7A C. WRIGHT \& A. MILleR, supra note 2, § 1839, at 427; Haudek, supra note 4, at 770.

7. See FED. R. Civ. P. 23.1 advisory committee note.

8. Schreiber v. Butte Copper \& Zinc Co., 98 F. Supp. 106, 112 (S.D.N.Y. 1951 ).

9. 7A C. Wright \& A. Miller, supra note 2, § 1797, at 226, $\$ 1839$, at 427; see Feder v. Harrington, 58 F.R.D. 171,174 (S.D.N.Y. 1972).

10. 7A C. WRight \& A. Miller, supra note 2, § 1839, at 427; cf. Girsh v. Jepson, 521 F.2d 153, 157-60 (3d Cir. 1975); Himmelblau v. Haist, 195 F. Supp. 356, 357 (S.D.N.Y. 1971); Weiner v. Winters, 50 F.R.D. 306, 309 (S.D.N.Y. 1970) (cases treating class actions and shareholder derivative suits interchangeably when discussing problems inherent in both)

11. Prior to the adoption of Rule 23 (c), it was widely accepted that a derivative plaintiff owed no duty to the corporation. Because the plaintiff bore all the expenses of the action, he possessed absolute discretion over the termination of the suit. As a result, the parties often agreed on a "buyout" arrangement whereby the plaintiff simply voluntarily dismissed his suit in exchange for consideration greater than his individual interest. The defendant stood to gain a great deal from "buying off" the plaintiff at inflated amounts since the derivative suit sought a much larger sum of money. Other shareholders possessed no right to participate in the proceeds of the "private settlement," and, moreover, had no standing to object to the action's termination. Once the suit was terminated, the right of fellow stockholders to intervene also ceased. At this point, the statute of limitations or laches often barred other shareholders from bringing a new action on the same grounds. The state of the law clearly encouraged vexatious litigation by plaintiffs hoping to secure a private settlement despite the dubious merit of their claims. Private settlements also enabled corporate defendants to suppress meritorious claims via the "buy-out" arrangement. Rule 23(c) and its progeny-Rules 23(e) and 23.1-were designed to curb these problems by requiring court approval and notice to shareholders before a derivative suit could be dismissed. See Haudek, supra note 4, at 768-70; Moore \& Cohn, Federal Class Actions, 32 ILl. L. Rev. 307, 321 -25 (1937); cf. Note, Recurrent Problems in Action Brought on Behalf of a Class, 34 Colum. L. REv. 118, 123-127 (1934). 
plaintiff is persuaded to abandon his suit in return for payments vastly in excess of his individual equity interest. ${ }^{12}$ In other words, judicial scrutiny and notice to shareholders of a proposed settlement protect nonparty shareholders from "fainthearted" plaintiffs who compromise their claims in exchange for individual satisfaction. ${ }^{13}$ Second, the notice requirement ${ }^{14}$ not only provides stockholders with an opportunity to be heard, but also broadens the informational foundation upon which the court will evaluate the settlement. ${ }^{15}$ Finally, the notice and court approval requirements minimize the danger that, due to the general contingent nature of fee recovery in derivative actions, the plaintiff shareholder's attorney may compromise his client's interest by accepting an inadequate settlement to secure his compensation and avoid the risk of litigation. ${ }^{16}$

Thus, the purpose behind obtaining judicial approval of shareholder derivative settlements is to protect shareholders from unjust or collusive settlements. ${ }^{17}$ Court approval of a derivative settlement, assuming the notice requirement is met, operates as a final judgment on the merits. ${ }^{18}$ This finality ensures an equitable result by barring any subsequent action by the corporation or nonparty shareholders on identical or substantially similar claims. ${ }^{19}$

12. See Schlusselberg v. Colonial Management Assocs., 389 F. Supp. 733, 741 (D. Mass. 1974); Birnbaum v. Birrel, 17 F.R.D. 409, 411 (S.D.N.Y. 1955).

13. See In re Corrugated Container Antitrust Litig., 643 F.2d 195, 223-25 (5th Cir. 1981), cert. denied, 456 U.S. 998 (1982); Norman v. McKee, 431 F.2d 769, 774 (9th Cir. 1970), cert. denied, 401 U.S. 912 (1971); Webster Eisenlohr, Inc. v. Kalodner, 145 F.2d 316, 320 (3d Cir. 1944), cert. denied, 325 U.S. 867 (1945).

14. Rule 23.1 requires notice of a proposed settlement or dismissal in such manner as the court directs. Notice is generally mailed to each shareholder of record. Boggess v. Hogan, 410 F. Supp. 433, 442 (N.D. Ill. 1975); Birnbaum v. Birrel, 17 F.R.D. 409, 412 (S.D.N.Y. 1955). However, New York, for example, requires notice of a settlement only if "the interests of the shareholders . . . will be substantially affected. . . ." N.Y. Bus. CoRP. LAw $\$ 626(d)$ (McKinney 1984). Although notice ordinarily is mailed, the court may permit notice by publication when the settlement recovery, relative to the expense of individual notification, is not cost beneficial. See Blau v. Brown \& W. Nuclear, Inc., 1967-1969 FED. SEC. L. REP. (CCH) ף 92,263 (S.D.N.Y. 1968).

The settlement notice must describe the terms of the proposed settlement, including any fee agreement between the plaintiff's counsel and the defendants. The notice also must identify the time and place for the shareholders to raise objections and must state that the settlement stipulation is on file with the court and available for public inspection. Haudek, supra note 4, at 783-84, 787-88; 7A C. WRIGHT \& A. Miller, supra note 2, $\$ 1839$, at 429-30; see also Sweet v. Birmingham, 65 F.R.D. 551, 556 (S.D.N.Y. 1975); Rogers v. Hull, 34 F. Supp. 358, 366 (S.D.N.Y. 1940) (specifically requiring shareholder notice and court approval of a fee arrangement). The purpose of such notice is to provide shareholders with sufficient information to decide whether they should agree with or object to the proposed settlement. The expense of such notification is borne by the beneficiary corporation. Haudek, supra note 4 , at 788 .

15. For further discussion, see infra notes 104-110 and accompanying text.

16. For further discussion, see infra notes 89-98 and accompanying text.

17. Schlusselberg v. Colonial Management Assocs., Inc., 389 F. Supp. 733, 741 (D. Mass. 1974).

18. See Nathan v. Rowan, 651 F.2d 1223, 1226 (6th Cir. 1981); Stella v. Kaiser, 218 F.2d 64, 6567 (2d Cir. 1954), cert. denied, 350 U.S. 835 (1955); Breswick \& Co. v. Briggs, 135 F. Supp. 397, 404 (S.D.N.Y. 1955); Liken v. Shaffer, 64 F. Supp. 432, 443 (N.D. Iowa 1946).

19. See cases cited supra note 18. When there is insufficient notice of the settlement's content, however, the settlement is binding only upon the named parties to the action. See generally $7 \mathrm{~A} C$. Wright \& A. Miller, supra note 2, $\$ 1840$, at 438-42. Furthermore, the court-approved settlement is not res judicata as to any cause of action a stockholder possesses in his own right against the corporation or its directors and officers. Liken v. Shaffer, 64 F. Supp. 432, 442 (N.D. Iowa 1946). 


\section{B. Settlement of a Shareholder Derivative Action-An Illustration}

A typical shareholder derivative suit is filed either by a single shareholder or by a group of minority shareholders who believe the corporation has been wronged and that its directors and officers refuse to seek redress. ${ }^{20}$ Before filing a derivative action, the plaintiff shareholder must make a formal demand on the board of directors to remedy the corporate injury, ${ }^{21}$ unless a majority of the board has participated in the alleged wrongdoing thereby rendering any such demand futile. ${ }^{22}$ The derivative action is comprised of three parties: the complaining shareholder, the beneficiary corporation, and the alleged wrongdoer. Under Rule 19 of the Federal Rules of Civil Procedure, ${ }^{23}$ the corporation, despite failing to enforce the claim in its own right, is an indispensable party to the litigation and must be joined as a nominal defendant. ${ }^{24}$

20. C. Wright, Law of Federal Courts 487-88 (4th ed. 1983).

21. Fed. R. CIv. P. 23.1; see also Cohen v. Beneficial Indus. Loan Corp., 337 U.S. 541, 543 (1949); Hawes v. Oakland, 104 U.S. 450 (1882). The purpose behind such a requirement is to allow the corporation an opportunity to vindicate its own rights before a shareholder attempts to do so on its behalf. Cohen, 337 U.S. at 548; Hawes, 104 U.S. at 460-61.

22. See Smith v. Sperling, 354 U.S. 91, $92-93$ (1959); Hawes v. Oakland, 104 U.S. 450, 461 (1882); Clark v. Lomas \& Nettleton Fin. Corp., 625 F.2d 49, 53 (5th Cir. 1980), cert. denied, 450 U.S. 1029 (1981). The plaintiff shareholder is also required to make a similar demand on the remaining shareholders if a majority vote of these shareholders could rectify the alleged wrong. See Surowitz v. Hilton Hotels, 383 U.S. 363, 365 n.4 (1966); Hawes v. Oakland, 104 U.S. at 461; Herpich v. Wallace, 430 F.2d 792, 817-18 (5th Cir. 1970); Levitt v. Johnson, 334 F.2d 815, 817-18 (1st Cir. 1964), cert. denied, 379 U.S. 961 (1965). For further discussion, see also H. Henn \& J. AleXander, supra note 2, at 1069-73; 7A C. WRIGHT \& A. MiLler, supra note 2, § 1831, at 373, §1832, at 383.

23. A person who is subject to service of process and whose joinder will not deprive the court of jurisdiction over the subject matter of the action shall be joined as a party in the action if . . . he claims an interest relating to the subject of the action and is so situated that the disposition of the action in his absence may ... leave any of the persons already parties subject to a substantial risk of incurring double, multiple, or otherwise inconsistent obligations by reason of his claimed interest ...

FED. R. CIV. P. 19.

24. Koster v. American Lumbermens Mut. Cas. Co., 330 U.S. 518, 522-23 (1947); Tryforos v. Icarian Dev. Co., 518 F.2d 1258, 1264-65 (7th Cir. 1975), cert. denied, 423 U.S. 1091 (1976); Kaufman v. Dreyfus Fund, Inc., 434 F.2d 727, 734 (3d Cir. 1970), cert. denied, 401 U.S. 974 (1971). In addition, Federal Rule of Civil Procedure 82 provides that Rule 23.1 cannot expand the jurisdiction of United States district courts. Because the corporation is an indispensable party, its citizenship must be considered when federal subject matter jurisdiction is based on diversity of citizenship. A corporation is a citizen of the state of its incorporation as well as the state where it has its principal place of business. 28 U.S.C. $\$ 1332$ (c) (1982). "Complete diversity between the plaintiffs and defendants is required for there to be a controversy between citizens of different states." H. HENN \& J. Alexander, supra note 2, at 1025 . Therefore, the plaintiff cannot be a citizen of either the company's state of incorporation or its principal place of business for diversity jurisdiction to exist. Since the corporation is a nominal defendant, the real defendants typically will request the court to realign the corporation as a plaintiff in the hope of destroying diversity of citizenship. For example, "[s]uppose a New York resident who is a shareholder of a Pennsylvania corporation with principal place of business in Pennsylvania sues derivatively in a federal district court an alleged wrongdoer who is a citizen of Pennsylvania. If the corporation is realigned as the real party plaintiff [diversity of citizenship is destroyed]." Id. For many years the confusion over the proper alignment of the corporation forced courts to "look behind the pleadings and thereby realign litigants in accordance with their real interests. This in effect often meant a preliminary determination on the merits to resolve the jurisdictional issue." Id. at 1026; see, e.g., Doctor v. Harrington, 196 U.S. 579 (1905); Carr v. Beverly Hills Corp., 237 F.2d 323 (9th Cir. 1956), rev'd per curiam, 354 U.S. 917 (1957). Whether to treat the corporation as a real party plaintiff or a nominal defendant depended on the degree of antagonism displayed by the corporation toward the defendants. See H. Henn \& J. Alexander, supra 
Settlement negotiations in the typical derivative action begin once the complaint has been filed. Not surprisingly, settlement agreements are viewed favorably by the courts because they are a means of amicably resolving shareholder concerns and avoiding costly trials. ${ }^{25}$ Courts also strongly encourage settlements to avoid the potential uncertainties and expenses incident to wasteful litigation. ${ }^{26}$ Despite the important policy considerations favoring settlements, the law will sanction such an agreement only if reached fairly, ${ }^{27}$ that is, free from any collusion or improper conduct. ${ }^{28}$

After the settlement agreement is executed, it is generally submitted to the court for approval with the plaintiff's petition for attorney fees and a request for a hearing on the settlement's substantive fairness. ${ }^{29}$ Prior to the settlement hearing, however, notice of the terms of the settlement, including any counsel fees petitioned for by the plaintiff, is mailed to the shareholders of record. ${ }^{30}$ If the court approves the settlement, a consent order is issued and the judgment precludes further litigation of such claims by the corporation and its shareholders. Both judicial rejection and approval of a proposed settlement are appealable decisions. ${ }^{31}$ Although the corporation is a nominal defendant, it is entitled to receive any settlement recovery. ${ }^{32}$ As a

note 2, at 1026; 7A C. Wright \& A. Miller, supra note 2, § 1822, at 306-07. Confusion over the level of antagonism necessary to establish the corporation's jurisdictional status was effectively resolved by the companion cases of Swanson v. Traer, 354 U.S. 114 (1957), and Smith v. Sperling, 354 U.S. 91 (1957). Following these decisions, courts were no longer required to probe the merits of the case to determine degrees of antagonism, for both opinions made it clear that the level of antagonism was to be determined "on the face of the pleadings and by the nature of the controversy." Smith v. Sperling, 354 U.S. at 96 . The gravamen of these decisions, as pointed out by Justice Frankfurter in his dissenting opinion to both cases, is "that collusion aside, whenever a corporation refuses to bring a suit and a derivative suit is brought by stockholders on its behalf, the corporation is always to be aligned as a defendant for purposes of determining diversity jurisdiction." Id. at 98 (Frankfurter, J., dissenting); see also Swanson v. Traer, 354 U.S. 114,117 (1957) (Frankfurter, J., dissenting). Consequently, if the persons in control of the corporation refuse to remedy the disputed transaction or if the demand requirement is excused, the corporation must be aligned as a nominal defendant. See H. Henn \& J. Alexander, supra note 2, at 1026; 7 A C. Wright \& A. Miller, supra note $2, \S 1822$, at 308 . For further analysis, see H. HenN \& J. Alexander, supra note 2, at 1025-26, 7A C. Wright \& A. Miller, supra note 2, $\$ 1822$, at 301-11. It should be noted, however, that in the event realignment creates diversity of citizenship, a federal court cannot entertain the action if the motion for realignment is intended to create federal subject matter jurisdiction. See Fed. R. Crv. P. 23.1; e.g., Rogers v. Valentine, 426 F.2d 1361, 1363 (2d Cir. 1970).

25. Edwards v. Travelers Ins. Co., 563 F.2d 105, 116 (6th Cir. 1977); Pearson v. Ecological Science Corp., 522 F.2d 171, 175-76 (5th Cir. 1975), cert. denied, 425 U.S. 912 (1976); D.H. Overmeyer Co. v. Loflin, 440 F.2d 1213, $1214-15$ (5th Cir.), cert. denied, 404 U.S. 851 (1971); see also Jamison v. Butcher \& Sherrerd, 68 F.R.D. 474, 481 (E.D. Pa. 1975).

26. Pfizer, Inc. v. Lord, 456 F.2d 532, 543 (8th Cir.), cert. denied, 406 U.S. 976 (1972); In re Corrugated Container Antitrust Litig., 556 F. Supp. 1117, 1157 (S.D. Tex. 1982); Stull v. Baker, 410 F. Supp. 1326, 1333-34 (S.D.N.Y. 1976).

27. Randolph v. Ottenstein, 238 F. Supp. 1011,1013 (D.D.C. 1965).

28. In re Scientific Control Corp., 80 F.R.D. 237, $241-42$ (S.D.N.Y. 1978).

29. 7A C. Wright \& A. Miller, supra note 2, § 1839, at 429; Haudek, The Settlement and Dismissal of Stockholders' Actions-Part II: The Settlement, 23 Sw. L.J. 765 (1969).

30. See supra notes $11-15$ and accompanying text.

31. Norman v. McKee, 431 F.2d 769, $772-74$ (9th Cir. 1970), cert. denied, 401 U.S. 912 (1971).

32. Ross v. Bernhard, 396 U.S. 531, 538-39 (1970); In re Pittsburgh \& Lake Erie R.R. Sec. \& Antitrust Litig., 543 F.2d 1058, 1068 (3d Cir. 1976); Sweet v. Bermingham, 65 F.R.D. 551, 553 (S.D.N.Y. 1975). When the defendants own a large majority of the corporate stock, however, the recovery accrues directly to the minority shareholders rather than the corporation. In this situation, 

compensate counsel who incurred the risk of litigation and obtained the recovery. ${ }^{42}$

\section{The Criteria for Court Approval of Proposed Settlements in Shareholder Derivative Litigation}

The decision whether to approve a proposed settlement in a shareholder derivative suit is committed to the sound discretion of the trial court. ${ }^{43} \mathrm{~A}$ reviewing court will not reverse this decision unless the trial court clearly abused its broad discretion. ${ }^{44}$ Courts have considered a number of relevant factors in deciding whether to approve a settlement. Accordingly, this note seeks (1) to alleviate confusion by consolidating these different factors into a working model (the "Model") for future court application, and (2) to suggest alternatives to the highly deferential level of scrutiny courts presently accord settlements between plaintiff's counsel and the defendant.

1. Synthesizing Present Approaches into a Unified Model. It is well established that "[b]efore approving the settlement of a derivative action, the [c]ourt must be satisfied that the compromise 'fairly and adequately serves the interests of the corporation on whose behalf the action was instituted." "45 "[W]hether another team of negotiators might have accomplished a better settlement," however, "is a matter equally comprised of conjecture and irrelevance." 46 The burden of proving a settlement's fairness and adequacy falls squarely on the proponents of the compromise. ${ }^{47}$ Since courts often encounter difficulty applying this general standard to complex settlements, the Model suggests dividing the standard into two subparts-fairness and adequacy-by applying a two-tiered system of review. ${ }^{48}$

42. Mills v. Electric Auto-Lite Co., 396 U.S. 375, $391-92$ (1970); Bailey v. Meister Brau, Inc., 378 F. Supp. 883, 886 (N.D. Ill. 1974) (dictum), rev'd on other grounds, 535 F.2d 982 (7th Cir. 1976); 7A C. Wright \& A. Miller, supra note 2, $\$ 1841$, at 443-44. Such contributions, however, are tax deductible. B.T. Harris Corp. v. Commissioner, 30 T.C. 635 (1958); Shoe Corp. of Am. v. Commissioner, 29 T.C. 297 (1957).

43. Shlensky v. Dorsey, 574 F.2d 131, 147 (3d Cir. 1978); Girsh v. Jepson, 521 F.2d I53, 156 (3d Cir. 1975); Cohen v. Young, 127 F.2d 721, 725-26 (6th Cir. 1942); Berger v. Dyson, 111 F. Supp. 533, 535 (D.R.I. 1953); see also Rosenfeld v. Black, 336 F. Supp. 84, 87 (S.D.N.Y. 1972); Birnbaum v. Birrell, 17 F.R.D. 409, 411 (S.D.N.Y. 1955).

44. United Founders Life Ins. Co. v. Consumer Nat'l Life Ins. Co., 447 F.2d 647, 655 (7th Cir. 1971); see also In re Pittsburgh \& Lake Erie R.R. Antitrust Litig., 543 F.2d 1058, 1070 (3d Cir. 1976); Girsh v. Jepson, 521 F.2d 153, 156 \& n.7 (3d Cir. 1975).

45. Mathes v. Roberts, 85 F.R.D. 710,713 (S.D.N.Y. 1980); Lewis v. Anderson, 81 F.R.D. 436, 438 (S.D.N.Y. 1978) (both quoting Republic Nat'l Life Ins. Co. v. Beasley, 73 F.R.D. 658,667 (S.D.N.Y. 1977)); see also Siegal v. Merrick, 590 F.2d 35, 37-38 (2d Cir. 1978); Desimone v. Industrial Bio-Test Laboratories, Inc., 83 F.R.D. 615, 618 (S.D.N.Y. 1979); Weiss v. Drew Nat'l Corp., 465 F. Supp. 548, 551 (S.D.N.Y. 1979).

46. In re Corrugated Antitrust Litig., 643 F.2d 195, 212 (5th Cir. 1981), cert. denied, 457 U.S. 998 (1982).

47. Greenspun v. Bogan, 492 F.2d 375, 378 (1st Cir. 1974); Weiss v. Drew Nat'l Corp., 465 F. Supp. 548, 551 (S.D.N.Y. 1979); Jamison v. Butcher \& Sherrerd, 68 F.R.D. 479, 482 (E.D. Pa. 1975); Norman v. McKee, 290 F. Supp. 29, 32 (N.D. Cal. 1968).

48. For decisions suggesting the application of the proposed two-tier fairness and adequacy system of review, compare In re Montgomery County Real Estate Antitrust Litig., 83 F.R.D. 305, 315 (D. Md. 1979), with Desimone v. Industrial Bio-Test Laboratories, Inc., 83 F.R.D. 615, $618-19$ (S.D.N.Y. 1979). 
a. Ensuring fairness in the settlement. Prior to evaluating the adequacy of the corporation's net recovery or nonpecuniary relief, the reviewing court should consider the propriety or fairness of the settlement negotiations themselves. ${ }^{49}$ The purpose of this initial review is to alert the court to possible collusive settlement negotiations between plaintiff's counsel and the defendants. ${ }^{50}$ Any evidence of improper bargaining should signal the court to increase its scrutiny of the settlement's adequacy, ${ }^{51}$ insofar as the probability of a collusive settlement producing an inadequate recovery is substantial. ${ }^{52}$

Factors tending to reveal the "fairness" of a settlement are obviously those that indicate the presence or absence of collusion among parties. Because of the danger that plaintiff's counsel might compromise a suit to insure his fee, the court must determine that the settlement was reached as a result of good faith bargaining at arm's length. ${ }^{53}$ To facilitate this initial investigation, the Model suggests that courts impose on parties an obligation to satisfy the following requirements as a type of litmus test for fairness:

a. Plaintiff's and defendant's counsel should each submit an affidavit assuring the court and the shareholders of arm's length bargaining and adherence to the ban on contemporaneous negotiations. ${ }^{54}$

b. Proponents' counsel should be "experienced, able, and respected members of the bar ... who have represented numerous clients in similar cases." 55 Such experience should help produce a beneficial settlement without saddling the recovery with extensive litigation expenses.

c. Proponents' counsel should be continuing with trial preparations during settlement negotiations, thereby demonstrating their willingness to go to trial if in the clients' best interests. ${ }^{56}$

d. Proponents' counsel should have conducted "sufficient discovery to enable counsel to act intelligently." 57

49. See Saylor v. Bastedo, 100 F.R.D. 44, 49 (S.D.N.Y. 1983); In re Montgomery County Real Estate Antitrust Litig., 83 F.R.D. 305, 315 (S.D.N.Y. 1979).

50. Saylor v. Bastedo, 100 F.R.D. 44, 49 (S.D.N.Y. 1983).

51. See Mendoza v. United States, 623 F.2d 1338, 1353 (9th Cir. 1980), cert. denied, 450 U.S. 912 (1981).

52. See, e.g., Jamison v. Butcher \& Sherrerd, 68 F.R.D. 479 (E.D. Pa. 1975); Norman v. McKee, 290 F. Supp. 29 (N.D. Cal. 1968), affd, 431 F.2d 769 (1970), cert. denied, 401 U.S. 912 (1971).

In Jamiscn, for example, after simultaneous negotiations of the settlement award and attorney fees, plaintiff's counsel proposed a settlement providing the plaintiff class with damages to which they were already entitled under a prior SEC victory. In consideration of $\$ 50,000$ in attorney fees, plaintiff's counsel essentially recommended a settlement that had no value to his client. Therefore, to review best the adequacy of a proposed settlement, the Model recommends prior investigation into the fairness of the negotiation process.

53. In re Montgomery County Real Estate Antitrust Litig., 83 F.R.D. 305, 315 (D. Md. 1979); see Desimone v. Industrial Bio-Test Laboratories, Inc., 83 F.R.D. 615, 618 (S.D.N.Y. 1979); Weiss v. Drew Nat'l Corp., 465 F. Supp. 548, 551 (S.D.N.Y. 1979); Feder v. Harrington, 58 F.R.D. 171, 17475 (S.D.N.Y. 1972); Burger v. CPC Int'l, Inc., 76 F.R.D. 183, 186 (S.D.N.Y. 1977).

54. Desimone v. Industrial Bio-Test Laboratories, Inc., 83 F.R.D. 615, 618 \& n.2 (S.D.N.Y. 1979).

55. Burger v. CPC Int'l Inc., 76 F.R.D. 183, 186 (S.D.N.Y. 1977); see Desimone v. Industrial BioTest Laboratories, Inc., 83 F.R.D. 615, 618-19 (S.D.N.Y. 1979); In re Montgomery County Real Estate Antitrust Litig., 83 F.R.D. 305, 315 (D. Md. 1979); Feder v. Harrington, 58 F.R.D. 171, 174-75 (S.D.N.Y. 1972).

56. Burger v. CPC Int'l, Inc., 76 F.R.D. 183, 186 (S.D.N.Y. 1977).

57. Desimone v. Industrial Bio-Test Laboratories, Inc., 83 F.R.D. 615, 618 (S.D.N.Y. 1979); Weiss v. Drew Nat'l Corp., 465 F. Supp. 548 (S.D.N.Y. 1979); Feder v. Harrington, 58 F.R.D. 171 , 174-75 (S.D.N.Y. 1972); see In re Montgomery County Real Estate Antitrust Litig., 83 F.R.D. 305, 315 
e. Proponents' counsel should demonstrate that "the number of objectants [sic] or their relative interest is small." 58

The failure to meet any or all of these requirements will rarely result in automatic rejection of the settlement; however, discovery of such a failure should alert courts to an increased potential for collusion thereby leading to intensified judicial scrutiny of the settlement's adequacy. ${ }^{59}$ Alternatively, if the proponents satisfy the requirements and thus establish the decorum of the negotiations, there should be a presumption in favor of the settlement. ${ }^{60}$

b. Establishing the adequacy of the settlement. After determining the fairness of the settlement negotiations, the court must appraise the adequacy of the settlement award.61 To best assist the court in making this determination, the Model recommends judicial consideration of the following factors:

a. First and foremost, the strength of the plaintiff's case in light of evidence of the best possible recovery, balanced against the proposed settlement award. ${ }^{62}$

b. "[T]he complexity, expense and probable duration of continued litigation."'63

c. The risks of establishing liability and proving damages. ${ }^{64}$

d. The solvency of the defendant, that is, his ability to withstand a subsequent greater judgment. ${ }^{65}$

e. The type and number of objections from dissatisfied shareholders. ${ }^{66}$

(D. Md. 1979); Burger v. CPC Int'l, Inc., 76 F.R.D. 183, 186 (S.D.N.Y. 1979). Failure to provide objectors with adequate discovery may cause a court to reject a proposed settlement. Girsh v. Jepson, 521 F.2d 153, 157-60 (3d Cir. 1975).

58. See Desimone v. Industrial Bio-Test Laboratories, Inc., 83 F.R.D. 615, 618 (S.D.N.Y. 1979); Burger v. CPC Int'l, Inc., 76 F.R.D. 183, 186 (S.D.N.Y. 1979).

59. See In re Montgomery County Real Estate Antitrust Litig., 83 F.R.D. 305, 315 (D. Md. 1979).

60. See Desimone v. Industrial Bio-Test Laboratories, Inc., 83 F.R.D. 615, 619 (S.D.N.Y. 1979); Feder v. Harrington, 58 F.R.D. 171 , 175 (S.D.N.Y. 1972).

61. See In re Montgomery County Real Estate Antitrust Litig., 83 F.R.D. 305, $315-17$ (D. Md. 1979).

62. See Saylor v. Bastedo, 100 F.R.D. 44, 49 (S.D.N.Y. 1983); Krasner v. Dreyfus Corp., 500 F. Supp. 36, 44 (S.D.N.Y. 1980); Mathes v. Roberts, 85 F.R.D. 710, 714 (S.D.N.Y. 1980); Lewis v. Anderson, 81 F.R.D. 436, 438 (S.D.N.Y. 1978). Failure to provide the court with estimates of the best possible recovery may result in settlement rejection. See Krasner v. Dreyfus Corp., 500 F. Supp. at 45.

63. Desimone v. Industrial Bio-Test Laboratories, Inc., 83 F.R.D. 615, 619 (S.D.N.Y. 1979); see Shlensky v. Dorsey, 574 F.2d 131, 147 (3d Cir. 1978); Girsh v. Jepson, 521 F.2d 153, 157 (3d Cir. 1975); Saylor v. Bastedo, 100 F.R.D. 44, 49 (S.D.N.Y. 1983); Lewis v. Anderson, 81 F.R.D. 436,439 (S.D.N.Y. 1978); Burger v. CPC Int'l, Inc., 76 F.R.D. 183, 186 (S.D.N.Y. 1977).

64. See Shlensky v. Dorsey, 574 F.2d 131, 147 (3d Cir. 1978); Girsh v. Jepson, 521 F.2d 153,157 (3d Cir. 1975); Saylor v. Bastedo, 100 F.R.D. 44, 49 (S.D.N.Y. 1983); Desimone v. Industrial Bio-Test Laboratories, Inc., 83 F.R.D. 615,619 (S.D.N.Y. 1979).

65. Girsh v. Jepson, 521 F.2d 153, 157 (3d Cir. 1975); Desimone v. Industrial Bio-Test Laboratories, Inc., 83 F.R.D. 615,619 (S.D.N.Y. 1979).

66. See Shlensky v. Dorsey, 574 F.2d 131, 148 (3d Cir. 1978); Greenspun v. Bogan, 492 F.2d 375, 379-80 (1st Cir. 1974); Saylor v. Bastedo, 100 F.R.D. 44, 49 (S.D.N.Y. 1983); Desimone v. Industrial Bio-Test Laboratories, Inc., 83 F.R.D. 615, 619 (S.D.N.Y. 1979); Burger v. CPC Int'l, Inc., 76 F.R.D. 183, 186 (S.D.N.Y. 1978). 
f. The settlement's approval by an independent board of directors and/or a majority of shareholders. ${ }^{67}$

g. The amount of attorney fees for which plaintiff's counsel plans to petition.

h. The type and amount of indemnification payments that may be paid to individual defendants.

i. The type and amount of corporate reimbursement available through indemnification insurance policies on officers' and directors' liability.

To ensure proper evaluation of the adequacy of a proposed settlement, plaintiff's counsel should submit a reasonably accurate (but not negotiated) request for attorney fees prior to court approval. This fee request, coupled with information from factors $g$ through $i$, provides the court and shareholders with a complete picture of the estimated net recovery, which will augment their ability to evaluate the settlement. ${ }^{68}$

2. Judicial Scrutiny. "It is not necessary in order to determine whether an agreement of settlement and compromise shall be approved that the court try the case [on the merits]. .. . Such a standard of scrutiny would emasculate the very purpose for which settlements are made."69 That purpose is twofold: " $[t]$ o avoid the trial of sharply disputed issues and to dispense with wasteful litigation."70 The court, however, should carefully avoid "merely rubber stamp[ing] whatever settlement is proposed by the parties to a shareholder derivative action."71 Rather, the court should exercise its own independent and objective judgment to form an opinion on the merits of the plaintiff's claim in order to protect the interests of nonparty shareholders. ${ }^{72}$

67. Greenspun v. Bogan, 492 F.2d 375, 378 (lst Cir. 1974).

68. See In re General Motors Corp. Engine Interchange Litig., 594 F.2d 1106, 1130-31 (7th Cir.), cert. denied, 444 U.S. 870 (1979).

To illustrate, assume that plaintiff's counsel submits a $\$ 1,000,000$ settlement for court approval, collusive negotiations do not occur, and the amount is reasonable in light of factors $a$ through $f$. Without knowledge of factors $g, h$, and $i$, the recovery flowing to the corporation may appear adequate and, as a result, the number of objectors will be small. However, for further illustration, assume the following facts: plaintiff's counsel plans upon settlement approval to request attorney fees of $\$ 250,000$, the corporation indemnifies its officers and directors against fines and litigation expenses (including reasonable attorney fees and amounts paid in settlement), the defendants incur $\$ 100,000$ in litigation expenses, and the corporation maintains an indemnification insurance policy for $70 \%$ of any indemnification payments. The knowledge of factors $f$ through $h$ reduces a gross settlement of $\$ 1,000,000$ to a net recovery of $\$ 720,000$. Therefore, every factor must be considered before a court can reasonably assess a settlement offer.

69. City of Detroit v. Grinnel Corp., 495 F.2d 448, 462 (2d Cir. 1974); see also Saylor v. Lindsley, 456 F.2d 896, 904 (2d Cir. 1972); In re Montgomery County Real Estate Antitrust Litig., 83 F.R.D. 305, 316 (D. Md. 1979).

70. Saylor v. Lindsley, 456 F.2d 896, 904 (2d Cir. 1972); In re Montgomery County Real Estate Antitrust Litig., 83 F.R.D. 305, 316 (D. Md. 1979).

71. See Greenspun v. Bogan, 492 F.2d 375, 378 (5th Cir. 1974); Mathes v. Roberts, 85 F.R.D. 710,714 (S.D.N.Y. 1980); Lewis v. Anderson, 81 F.R.D. 436,439 n.4 (S.D.N.Y. 1978).

72. Krasner v. Dreyfus Corp., 90 F.R.D. 665, 666-67 (S.D.N.Y. 1981); see United Founders Life Ins. Co. v. Consumers Nat'l Life Ins. Co., 447 F.2d 647, 655 (7th Cir. 1971); Desimone v. Industrial Bio-Test Laboratories, Inc., 83 F.R.D. 615, 619 (S.D.N.Y. 1979); Norman v. McKee, 290 F. Supp. 29, 32 (N.D. Cal. 1968), affd, 431 F.2d 769 (9th Cir. 1970), cert. denied, 401 U.S. 912 (1971). 
In evaluating a proposed settlement in a derivative action, the court's function is not to substitute its business judgment for that of the negotiators who bargained at arm's length. ${ }^{73}$ Such counsel are intimately associated with the litigation and consequently are far more able to weigh its relative strengths and weaknesses. ${ }^{74}$ As a result, the court seeks "only to insure that the arrangement is not so unfair as to require disapproval."75 Indeed, "[t]he fact that a proposed settlement may only amount to a fraction of the potential recovery does not, in and of itself, mean that the proposed settlement is [so] grossly inadequate [that it] should be disapproved."76 "The court . . . will not approve a settlement if it is unfair, but 'fairness' may be found anywhere within a broad range of lower and upper limits." 77 Because of the presumption in favor of settlements, the degree of scrutiny exercised by courts in evaluating them ${ }^{78}$ should be deferential provided the settlement negotiations are not collusive. Unless the settlement amount is woefully inadequate, ${ }^{79}$ the negotiations improper, ${ }^{80}$ or an objector brings a material point to the court's attention, ${ }^{81}$ no heightened scrutiny is employed and approval is highly probable. If the court discovers either the existence of or potential for collusion, however, judicial scrutiny applied in evaluating the settlement's adequacy should be increased. ${ }^{82}$

By applying the Model's two-tiered system of review, the court's initial evaluation of the settlement's fairness should also dictate the level of scrutiny applied in appraising its adequacy. The first tier inquiry, therefore, will reveal to courts when they should increase their scrutiny of settlements with collusive potential. The second tier analysis requires evaluation of the settlement's adequacy under a degree of scrutiny determined by the result of the first tier. In short, the Model is an analytical device designed to assist courts in monitoring proposed settlements. While no panacea to the conflict of interest problems inherent in shareholder derivative litigation, the Model goes far to ensure that the interests of plaintiff shareholders and the corporation are adequately safeguarded.

73. Jamison v. Butcher \& Sherrerd, 68 F.R.D. 479, 481 (E.D. Pa. 1975).

74. Krasner v. Dreyfus Corp., 90 F.R.D. 665, 667 (S.D.N.Y. 1981); Desimone v. Industrial BioTest Laboratories, Inc., 83 F.R.D. 615, 619 (S.D.N.Y. 1979); see Norman v. McKee, 290 F. Supp. 29, 32 (N.D. Cal. 1968), affd, 431 F.2d 769 (1970), cert. denied, 401 U.S. 912 (1971).

75. Desimone v. Industrial Bio-Test Laboratories, Inc., 83 F.R.D. 615, 619 (S.D.N.Y. 1979).

76. City of Detroit v. Grinnel Corp., 495 F.2d 448, 455 (2d Cir. 1974).

77. In re General Motors Corp. Engine Interchange Litig., 594 F.2d 1106, 1125 n.24 (7th Cir.), cert. denied, 444 U.S. 870 (1979).

78. See supra notes 43-81 and accompanying text.

79. See, e.g., Saylor v. Bastedo, 100 F.R.D. 44 (S.D.N.Y. 1983); Jamison v. Butcher \& Sherrerd, 68 F.R.D. 479 (E.D. Pa. 1975).

80. See Jamison v. Butcher \& Sherrerd, 68 F.R.D. 479 (E.D. Pa. 1975).

81. The degree of scrutiny the circuit normally exerts increases once a "complaining shareholder objects to the settlement." Saylor v. Bastedo, 100 F.R.D. 44, 49 (S.D.N.Y. 1983).

82. See Mendoza v. United States, 623 F.2d 1338, 1353 (9th Cir. 1980); $c f$ Jamison v. Butcher \& Sherrerd, 68 F.R.D. 479 (E.D. Pa. 1975) (rejecting proposed settlement because of potential for collusion). 
II

The Settlement Negotiation-A Conflict of Interest

\section{A. The Problem}

During settlement negotiations, counsel for plaintiff and defendant may agree on a proper fee award in addition to the settlement terms. In seeking to minimize its liability, the defendant may implicitly or even explicitly promise not to oppose the fees petitioned by plaintiff's counsel at the settlement hearing. 83

The "real" defendants-who are ordinarily corporate directors or officers-possess strong incentives for reaching a compromise. All states currently have statutes that indemnify directors, officers, and other corporate personnel against litigation expenses (including attorney fees) incurred in defending themselves. ${ }^{84}$ Under these statutes, indemnification is mandatory if the defendants prevail. On the other hand, if the defendants lose, indemnification is permissive (by vote of noninterested directors) provided the defendants' disputed behavior was conducted in good faith and in a manner reasonably believed to be in the best interests of the corporation. ${ }^{85}$ Because the settlement of a derivative suit is not a trial on the merits, ${ }^{86}$ no determination of liability or bad faith is ever made. ${ }^{87}$ Consequently, the defendants in effect possess an automatic right to indemnification unless the settlement stipulation expressly excludes it. ${ }^{88}$ For this reason, the defendants have a strong incentive not to litigate a derivative claim and thereby risk the loss of indemnification rights.

To the contrary, it has been argued that there are equally strong pressures opposing early settlement. The argument is premised on the assumption that the corporation, seeking to maximize its net recovery, will object to an inadequate settlement. This behavioral assumption, however, fails to recognize that the corporation often will receive a larger net recovery by agreeing to a small settlement amount than by insisting on litigation which would involve large indemnification expenses and plaintiff's counsel fees. But while the corporation's acquiescence in the settlement may produce shortterm corporate benefits, the willingness to settle frivolous or grossly inflated

83. See Zilker v. Klein, 540 F. Supp. $1196,1197-98$ (N.D. Ill. 1982); Haudek, supra note 4, at 784 .

84. See H. Henn \& J. Alexander, supra note 2, at 1121-32.

85. Id. at 1124 n.10; see, e.g., DEL. CODE ANN. tit. 8, § 145(a) (1984). Certain permissive statutes also provide for reimbursement of judgment amounts and/or fines. See H. Henn \& J. Alexander, supra note 2, at 1124 n. 10.

86. See City of Detroit v. Grinnel Corp., 495 F.2d 448, 462 (2d Cir. 1974); Saylor v. Lindsley, 456 F.2d 896, 904 (2d Cir. 1972); Saylor v. Bastedo, 100 F.R.D. 44, 49 (S.D.N.Y. 1983).

87. See Haudek, supra note 29, at 784-85.

88. Id.; see Principles of Corporate Governance: Analysis and Recommendations \$ 7.14 comment c (Council Draft No. 5, Nov. 14, 1984) [hereinafter cited as Corporate Governance (Nov. 1984)]; Principles of Corporate Governance: Analysis and Recommendations Intro. Note, at 5 , $\& \$ 7.13$ (Discussion Draft No. 1, June 3, 1985) [hereinafter cited as Corporate Governance (June 1985)]. 
claims only serves to encourage these claims, thereby imposing greater longterm costs on the corporation and the judicial system.

Likewise, numerous incentives drive plaintiff's counsel toward settlement. A settlement is virtually risk free since counsel will collect his fee, whether on a contingent or hourly basis, provided some identifiable benefit inures to the corporation. ${ }^{89}$ When the courts, defendants, and plaintiffs prefer to settle, the benefits of the adversary system are lost if plaintiff's counsel's preference for settlement is based upon personal pecuniary considerations rather than on his client's best interests. Since all the players may suddenly be on the same side, a conflict of interest frequently arises between plaintiff's counsel and his client:

Unlike other forms of litigation where the plaintiff's gain essentially comes at the
defendant's expense, the derivative action is a three-sided litigation with three
necessary parties: plaintiff, defendant, and the corporation. As a practical matter, the
first two parties can pass the costs of litigation onto the third by reaching a settlement
that maximizes their own [pecuniary] interests, but does not benefit the corporation. 90

Simply put, plaintiff's counsel can accept a smaller settlement in exchange for the defendant's acquiescence at the settlement hearing to a larger fee. The district court in Jamison $v$. Butcher $\mathcal{E}^{3}$ Sherrerd ${ }^{91}$ perceived just such a situation and, as a result, rejected the proposed settlement.92 In Jamison, the plaintiff class consisted of customers who sought to recoup losses suffered in purchasing securities from stockbrokers who allegedly sold shares without disclosing inside information. Plaintiffs alleged that the defendant stockbrokers who had nonpublic knowledge of the declining value of Penn Central Company securities sold Penn Central shares to the plaintiffs without disclosing the company's financial troubles. Prior to the purchasers' case, the SEC filed its own action on similar claims and reached a settlement with the stockbrokers whereby the brokers agreed to establish a $\$ 350,000$ escrow fund for disbursal to aggrieved customers. The proposed settlement provided that the defendants would distribute the $\$ 350,000$ escrow fund established by the SEC order to members of the Jamison class and pay $\$ 50,000$ in attorney fees to counsel for the class representatives. ${ }^{93}$ The court rejected the settlement because the class members were entitled to the $\$ 350,000$ escrow fund regardless of the outcome of the class action and, therefore, they would

89. See supra note 35 and accompanying text.

90. Corporate Governance (June 1985), supra note 88, Intro. Note, at 5 (citing Saylor v. Lindsley, 456 F.2d 896 (2d Cir. 1972)).

91. See Prandini v. National Tea Co., 557 F.2d 1015, 1017 (3d Cir. 1977); Saylor v. Lindsley, 456 F.2d 896, 900-01 (2d Cir. 1972); In $r e$ Montgomery County Real Estate Antitrust Litig., 83 F.R.D. 305, 315 (D. Md. 1979); Jamison v. Butcher \& Sherrerd, 68 F.R.D. 479, 484 (E.D. Pa. 1975); Philadelphia v. Chas. Pfizer \& Co., 345 F. Supp. 454, 471 (S.D.N.Y. 1972); Norman v. McKee, 290 F. Supp. 29, 36 (N.D. Cal. 1968), affd, 431 F.2d 769 (9th Cir. 1970), cert. denied, 401 U.S. 912 (1971); 3B J. Moore \& J. Kennedy, Moore's Federal Practice 1 23.1.25 (2d ed. 1984); Clermont \& Currivan, Improving on the Contingent Fee, 63 Cornell L. Rev. 529, 534 (1978); Coffee, Rescuing the Private Attorney General: Why the Model of One Lawyer as Bounty Hunter Is Not Working, 42 MD. L. REv. 215, 239-43 (1983); Haudek, supra note 29, at 784.

92. 68 F.R.D. 479, 484 (E.D. Pa. 1975).

93. Id. at $480-81$. 
receive no benefit from the proposed settlement. ${ }^{94}$ In rejecting the proposed settlement, the court admonished the parties for simultaneously negotiating settlement of the claims and the plaintiff's attorney fees: "[T]he present arrangement leaves the unfortunate impression that defendants are buying themselves out of a lawsuit by direct compensation to plaintiff's counsel." 95

The problem identified in Jamison is not unique to that case due to the incentives inherent in shareholder derivative litigation. As one court noted, "[a] plaintiffs lawyer who has an agreement that defendants will pay his fees has a strong motive to so conduct himself that defendants will not question or oppose the amount for which he ultimately applies as a fee." 96 By compromising the client's claim in exchange for a promise not to object to his petition for fees, plaintiff's counsel and the defendants gain to the corporation's economic detriment. ${ }^{97}$ As a consequence, plaintiff's counsel maximizes his profit and the defendants minimize their liability at the expense of the corporation. Since lawyers, like most people, are motivated by their economic self-interest (at least absent unusual altruism), it is hardly surprising to learn that occasionally counsel fails to champion zealously his client's cause. The next question, of course, is how to remedy this situation. Because the source of this conflict is divergent economic interests, the solution requires a realignment of traditional economic incentives between the plaintiff shareholder and his counsel. ${ }^{98}$

\section{III}

\section{Solving the Conflict of Interest Problem}

To remedy the conflict of interest problems encountered in settlement negotiation, at least three possible solutions are available:

(1) Strictly prohibiting contemporaneous negotiation of attorney fees and settlement awards between plaintiff's counsel and the defendant. ${ }^{99}$

94. Id. at 482 .

95. Id. at 484 .

96. Philadelphia v. Chas. Pfizer \& Co., 345 F. Supp. 454, 471 (S.D.N.Y. 1972).

97. Of course this type of egregious behavior is not without risk. Plaintiff's counsel would be susceptible to disciplinary action from the state board of ethics as well as independent lawsuits for malpractice and/or breach of fiduciary duty from piqued shareholders. See generally Saylor v. Lindsley, 456 F.2d 896, 900 (2d Cir. 1972); Alleghany Corp. v. Kirby, 333 F.2d 327, 347-48 (2d Cir. 1964) (Friendly, J., dissenting); Lewis v. Teleprompter Corp., 88 F.R.D. 11,18 (S.D.N.Y. 1980) (decisions identifying and describing plaintiff counsel's fiduciary duty to his client). Rather than file a separate lawsuit, the plaintiff shareholder could choose to appeal the settlement on grounds of inadequate representation. See FED. R. Civ. P. 23.1.

98. Cf. Prandini v. National Tea Co., 557 F.2d 1015, 1021 (3d Cir. 1977); Clermont \& Currivan, supra note 91, at 534-35; Coffee, supra note 91, at 237-38.

99. Hence, plaintiffs counsel should not discuss fees with the defendant until after the settlement is approved. Counsel for both sides would submit sworn affidavits that simultaneous negotiation of attorney fees and the settlement award did not occur.

Rejection of the settlement is not automatically required if there are "circumstances present which appear to neutralize the potential for impropriety." Mendoza v. United States, 623 F.2d 1338, 1353 (9th Cir. 1980), cert. denied, 450 U.S. 912 (1981) (presence of Department of Justice representative during the simultaneous negotiation of attorney fees and the settlement fund served to protect the 
(2) Requiring corporate reimbursement of litigation expenses, including attorney fees, for objectors whose participation improves the settlement or provides valuable information to the court.

(3) Altering the method of computing attorney fees to a "modified" percentage of recovery system.

\section{A. Banning Contemporaneous Negotiation}

Several federal courts have prohibited contemporaneous negotiation of the settlement amount and attorney fees. ${ }^{100}$ According to the Third Circuit,

Only after court approval of the damage settlement should discussion and negotiation of appropriate compensation for the attorneys begin. This procedure may not be particularly appealing to the parties, but it preserves the benefits of the adversary system. . . . Moreover, the merits of fee disputes become separated from those of damages, thus reducing the conflict of interests between client and attorney. This procedure would make the court's task less burdensome and remove a source of uneasiness over the settlement procedure without in any way impairing the power to set a proper fee. ${ }^{101}$

By prohibiting the simultaneous negotiation of attorney fees and the settlement award, the economic interests of the plaintiff's counsel and his client are realigned so that the adversary system can function properly. Plaintiff's counsel cannot strike a bargain with his adversary which maximizes both of their interests at the corporation's expense. In effect, a "two-step" process is created by requiring that negotiation, notice, and court approval of the settlement be completed before negotiation, notice, and court approval of attorney fees.

Although this solution is theoretically sound, two serious practical problems persist. First, there is no effective means of preventing collusion between plaintiff's counsel and the defendant. Although courts could require counsel to certify that simultaneous negotiations did not occur, detection and enforcement problems would remain. Not to be overlooked, an absolute prohibition against contemporaneous negotiations will likely encourage secret negotiations. ${ }^{102}$ Second, prior to any settlement agreement, potential objecting shareholders and the beneficiary corporation have a legitimate interest in knowing what impact litigation expenses will have on the net recovery. ${ }^{103}$ Therefore, disclosure of potential attorney fees is necessary to evaluate the eventual relief inuring to the corporation.

interests of the class). But "[i]t would rarely be an abuse of discretion for a trial court to reject a settlement proposal when such combined negotiations take place." Id.

100. Mendoza v. United States, 623 F.2d 1338, 1353 (9th Cir. 1980), cert. denied, 450 U.S. 912 (1981); Prandini v. National Tea Co., 557 F.2d 1015, 1021 (3d Cir. 1977); Lyon v. Arizona, 80 F.R.D. 665, 669 (D. Ariz. 1978); Jamison v. Butcher \& Sherrerd, 68 F.R.D. 479, 484 (E.D. Pa. 1975); Norman v. McKee, 290 F. Supp. 29, 36 (N.D. Cal. 1968), affd, 431 F.2d 769 (9th Cir. 1970), cert. denied, 401 U.S. 912 (1971).

101. Prandini v. National Tea Co., 557 F.2d 1015, 1021 (3d Cir. 1977).

102. Haudek, supra note 29 , at 784 .

103. Id. 


\section{B. Inducing Productive Objector Participation}

1. The Sole Adversary. The second means of ameliorating the conflict of interest problems in derivative suit settlements is to encourage productive participation by objectors in the settlement hearing. Objectors can play a critical and unique role in derivative suit settlements. Their importance stems from the unusual position of a court asked to approve a compromise reached by the parties. In contrast to the court's typical position as a neutral arbiter between two aggressive adversaries, the court is confronted in settlement hearings with parties who are in absolute agreement. No longer are the parties true opponents because "[o]nce a settlement is agreed, the attorneys for the plaintiff stockholders link arms with their former adversaries to defend the joint handiwork ...."104 The court, therefore, must attempt to see beyond the united front presented by the parties and decide whether the proposed settlement, including amounts to be withdrawn from the settlement fund to pay the plaintiff's attorney, is in the corporation's best interest.

Beyond the nonadversary nature of settlement hearings, judicial scrutiny is necessitated by the unusual and unnatural position of counsel. ${ }^{105}$ The corporation's counsel cannot be expected to champion corporate rights after the corporation has refused to initiate legal proceedings. Likewise, the shareholder's counsel, although purportedly vindicating corporate rights, often has personal economic incentives that compromise those rights. ${ }^{106}$ Absent objectors, the court is the only participant in the settlement proceedings whose perception of corporate interests is not colored by competing concerns. ${ }^{107}$ As a consequence, the court must conduct its own investigation of the shareholder's claims to determine the fairness and adequacy of the settlement. ${ }^{108}$

But the degree of judicial scrutiny given a settlement proposal is necessarily constrained by efficiency considerations. First, the value of settlement to the parties and the judicial system is diminished to the extent that the court conducts a lengthy, independent investigation of the settlement proposal. ${ }^{109}$ Second, courts are unaccustomed and unsuited to perform what is essentially an advocate's responsibility in an adversary legal system.

104. Alleghany Corp. v. Kirby, 333 F.2d 327, 347 (2d Cir. 1964) (Friendly, J., dissenting), cert. dismissed, 384 U.S. 28 (1965).

105. For a description of the settlement negotiations in a derivative suit and the participants economic interests (which are often at variance with the best interest of the corporation on whose behalf the suit is brought), see notes 83-98 and accompanying text.

106. See supra notes 89-91 and accompanying text.

107. The court may, however, look favorably upon the settlement reached by the parties because of the time and money saved by foregoing litigation of the claims.

108. See supra text accompanying notes 43-82.

109. In seeking to retain the efficiencies of settlement, courts have occasionally understated their role in the settlement proceedings. See, e.g., Krasner v. Dreyfus Corp., 90 F.R.D. 665, 666-67 (S.D.N.Y. 1981) ("In evaluating a proposed settlement in a derivative action, the Court's function is not to substitute [its] business judgment for that of the negotiators who bargained at arm's length, but only to insure that the arrangement is not so unfair as to require disapproval") (citation omitted). 
Consequently, objectors play an important role in settlement proceedings by enabling courts to perform a truly thorough evaluation of the settlement proposal $^{110}$ without undertaking a full-scale investigation of the shareholder's claims, the settlement negotiations, and the value of the settlement to the corporation. At the settlement hearing, the objector is the only remaining adversary of either the plaintiff or the defendant, the only participant whose purpose is to expose the weaknesses of the settlement agreement, and thus the only party that allows the court to perform its accustomed function of neutral arbitration.

The objector does not always benefit the corporation or the court, however. Both courts and commentators have characterized some objectors' participation as insubstantial, dilatory, and even extortionate.111 The objector may be regarded as a foe rather than a friend simply because he presents a new obstacle to a settlement desired by the plaintiff, the defendant, the corporation, and the overburdened reviewing court. ${ }^{112}$ Criticism of an objector's participation is legitimate, however, to the extent that the objector's counsel does not seek to prevent an inadequate settlement, but only to lay his claim to a share of the anticipated legal fees by threatening to delay approval of the settlement.

Because a court can discourage these counterproductive objectors by refusing to allow the objector's attorney any fees unless he has in fact conferred some benefit on the corporation, and because the cost of entertaining objections is relatively low, ${ }^{113}$ the advantages of objector participation outweigh its potential for abuse.

110. In a case . . . where there are [objecting shareholders], the court is aided in its task; the [settlement] proponents can be expected to present evidence and arguments suggesting that the settlements are within a "range of reasonableness" and the objectors will do the same for the contrary position. By weighing the competing evidence and evaluating the legal arguments, we think the court should be able to reach a just conclusion.

In re Corrugated Container Antitrust Litig., 643 F.2d 195, 213 (5th Cir. 1981), cert. denied, 456 U.S. 998 (1982).

Although the privileges objectors enjoy are subject to abuse, see infra notes $182-83$ and accompanying text, commentators generally agree that the value of objectors to the corporation on whose behalf the derivative suit is brought and to the integrity of the judicial process can surpass the costs incurred by giving objectors access to settlement proceedings. As one court has recognized, objectors provide the court with "the benefit of that broader information which comes from receiving advice as to the views of all parties concerned and from considering evidence proffered by them upon the relevant points of the case." Cohen v. Young, 127 F.2d 721, 725 (6th Cir. 1942), cert. denied, 321 U.S. 778 (1944); see Coffee, supra note 91, at 263; Haudek, supra note 29, at 803-04.

111. See Roman v. Master Indus., 1966-67 FED. SEC. L. ReP. (CCH) I 91,806, at 95,751 (July 20, 1966) (objector's attorney conferred no benefit on corporation but only made necessary additional hearing, caused "additional trouble and expense" to corporation, and took additional court time); Coffee, The Unfaithful Champion: The Plaintiff as Monitor in Shareholder Litigation, LAw \& CoNTEMP. Probs., Summer 1985, at 5, 30; see also Whittemore v. Sun Oil Co., 58 F.R.D 624, 627 (S.D.N.Y. 1973); Milstein v. Werner, 58 F.R.D. 544, 552 (S.D.N.Y. 1973).

Assuming dilatory conduct by objectors is a significant problem, it could be ameliorated by penalizing bad faith objections. See infra note 125 and accompanying text.

112. See, e.g., the court of appeal's designation of the district court's objector participation in Tryforos v. Icarian Dev. Co., 518 F.2d 1258, 1263-64 (7th Cir.), cert. denied, 423 U.S. 1091 (1975).

113. The expense of pursuing objections is borne by the objector or his attorney unless the objector produces some benefit for the corporation which would entitle him to an attorney fee allowance from the settlement fund. See infra note 117 and accompanying text. Irrespective of the 
Nevertheless, because the role of objectors is not an enviable one, courts are often deprived of their potentially valuable services. ${ }^{114}$ Few shareholders object to a proposed settlement of which they are notified because there is little-if any-economic incentive to do so. Unless a shareholder owns a great deal of stock, the value he personally would derive from an increase in the settlement amount is extremely minimal. ${ }^{115}$ Since few objectors have a sufficient financial interest in the settlement to pay their own attorney fees, the objector's attorney probably works on a contingency basis ${ }^{116}$ and therefore bears the risk of receiving no fees whatsoever. If the objector's attorney succeeds in preventing judicial approval of the settlement proposal and then is able to improve the terms of the settlement, he will receive a fee for his contribution. ${ }^{117}$ But if he fails to prevent court approval of the settlement or if he succeeds and his success results in further litigation rather than settlement of the derivative suit, the objector's attorney ordinarily receives no compensation, even if his objection was meritorious. ${ }^{118}$ Due to the riskiness of reward, it is only the very rare shareholder or his attorney who is willing to challenge a derivative settlement. Consequently, both the court and the corporation on whose behalf a derivative suit is brought lose the benefit of objectors' participation. ${ }^{119}$

2. Attracting Objectors. To encourage nonparty shareholders to participate in derivative suit settlement proceedings, courts should modify current practices in two ways. First, courts should make the role of objector more attractive by (1) giving the objector broad discovery privileges against both plaintiffs and defendants to insure that he has adequate information; and (2) rewarding the objector for providing valuable services by granting his attorney compensation while at the same time allocating the plaintiff shareholder's attorney fees in a way that discourages intervention so long as there is adequate representation of the derivative claim.

a. Discovery. Absent indications of bad faith, objectors should be permitted broad discovery upon a minimal showing of need. ${ }^{120}$ Objectors should have access to information relating to the underlying derivative claim, the value of the settlement, the settlement negotiations, and the work performed by

\footnotetext{
objector's success, the only cost imposed on the court is the time spent hearing the objector's contentions-probably considerably less time than would be consumed by a full and independent judicial investigation of the settlement terms.

114. Haudek, supra note 29 , at 805 .

115. Id.

116. Id.

117. White v. Auerbach, 500 F.2d 822, 828 (2d Cir. 1974); Green v. Transition Elecs. Corp., 326 F.2d 492, 498-99 (1st Cir. 1964); Winkelman v. General Motors Corp., 48 F. Supp. 504, 512 (S.D.N.Y. 1942), affd sub nom. Singer v. General Motors Corp., 136 F.2d 905 (2d Cir. 1943).

118. Whittemore v. Sun Oil Co., 58 F.R.D. 624, 627 (S.D.N.Y. 1973); Milstein v. Werner, 58 F.R.D. 544, 552 (S.D.N.Y. 1973); Newman v. Stein, 58 F.R.D. 540, 543-44 (S.D.N.Y. 1973).

119. Cohen v. Young, 127 F.2d 721, 725 (6th Cir. 1942), cert. denied, 321 U.S. 775 (1944); Haudek, supra note 29 , at 805 .

120. Cf. Rome v. Archer, 41 Del. 404, 416-17, 197 A.2d 49, 56 (1964).
} 
attorneys seeking compensation from the fund. Objectors can effectively protect corporate interests against inadequate settlements and exorbitant attorney fees only if they have access to all relevant information affecting the fairness on the proposed settlements.

$b$. Attorney fees. The objector should be rewarded for providing valuable services to the corporation and the court by awarding compensation to his attorney. As many courts have recognized, if the objector is successful in preventing court approval of the initial settlement and then improves the settlement terms, he should receive an allowance for attorney fees. ${ }^{121}$ That allowance should constitute a substantial percentage of the amount the settlement fund is increased by his efforts. As discussed more fully below, ${ }^{122}$ the court should award the objector's attorney fees on the basis of the additional recovery received by the corporation due to the objector's efforts. If the objector has produced only nonpecuniary benefits, the court should place a value on those benefits before awarding any fee to the objector. The percentage awarded to objectors could be adjusted upward or downward to encourage what the courts perceive to be the "right" amount of objector involvement in derivative suit settlements.

Even if the objector is not successful, however, the objector's participation may have saved the court time and money. ${ }^{123}$ If the objector has provided constructive, time-saving information to the court, he should receive modest attorney fees despite his lack of success in preventing the settlement or procuring more favorable settlement terms. ${ }^{124}$ Expanding the circumstances under which an objector receives attorney fees would promote productive nonparty shareholder participation in the settlement process by reducing the financial risk of objecting.

Admittedly, any reduction in the financial risk of objecting may also encourage frivolous or extortionate objections to proposed settlements. These objections may be avoided, however, not only by the court's strict refusal to award fees to their proponents but also by holding the objector's attorney liable for excessive costs incurred by the court because of the attorney's vexatious conduct. ${ }^{125}$

The second modification intended to promote objectors' participation goes to the very heart of the current practice and relates to the method by which plaintiff's counsel is compensated. Derivative suits are often brought by one or more shareholders represented by a single attorney or a single law firm. Other attorneys become involved after the suit is initiated by

121. See supra note 117 and accompanying text.

122. The objector's counsel fees should be calculated by the same method as the original plaintiff's counsel fees. For our suggested fee computation method, see infra pp. 258-60.

123. But see Frankenstein v. McCrory Corp., 425 F. Supp. 762, 767 (S.D.N.Y. 1977) (objectors caused court to spend more hours analyzing complex settlement agreement).

124. See Haudek, supra note 29 , at 805-06.

125. Imposing costs on the objector's attorney for vexatious conduct fits squarely within the language and purpose of federal judicial procedure. See 28 U.S.C. $\$ 1927$ (1982). 
representing shareholders who intervene or whose separate parallel suits are consolidated in the action. ${ }^{126}$ If the derivative suit is successful, resulting either in a settlement or a judgment in favor of the shareholders, an allowance for attorney fees is awarded from the fund created by the settlement or judgment to all counsel who performed productive work in the case. ${ }^{127}$ In derivative suits where intervention and consolidation produce numerous plaintiffs, the fee allowance is divided into many small awards. The generosity and frequency with which courts have awarded intervenors a portion of the fee allowance produces a strong economic incentive for intervention in derivative suits. ${ }^{128}$ Any shareholder who has an interest in the derivative litigation intervenes within a short time after litigation is initiated and takes part in the settlement negotiations. The intervenor's attorney then has precisely the same incentives as the original plaintiff's attorney to compromise the benefits accruing to the corporation in return for the defendant's implicit agreement not to oppose the joint request by the intervenor and original plaintiff's attorneys for a large fee allowance. ${ }^{129}$ If the shareholders who would intervene at the beginning of a derivative suit were discouraged from doing so but encouraged to participate as objectors after a tentative settlement had been reached, not only would the potential for collusion between the parties be reduced but the court would also enjoy the benefit of information independent of, and in opposition to, the united position presented by the parties.

Adjusting the method of allocating fees among the original plaintiff and intervenors would achieve a substantial shift away from intervention and toward objection. ${ }^{130}$ When initially faced with a derivative suit with the potential for attracting numerous intervenors, the court should appoint one or two of the attorneys representing different shareholders as lead counsel in the case. The attorneys should be carefully selected on the basis of their ability to represent the shareholders "fairly and adequately."131 Once the court determines that the shareholders are adequately represented, other shareholders could intervene although their attorneys would not be awarded a share of any fee allowance from the settlement fund. ${ }^{132}$ Those shareholders

126. See Haudek, supra note 29 , at 768-69.

127. See, e.g., Republic Nat'l Life Ins. Co. v. Beasley, 73 F.R.D. 658 (S.D.N.Y. 1977); Milstein v. Werner, 58 F.R.D. 544 (S.D.N.Y. 1973).

128. See Coffee, supra note 91 , at 233.

129. See supra notes $89-98$ and accompanying text.

130. Removing the financial incentives of intervention and consolidation would also address the "nonexcludability" problem recognized by Professor Coffee. In derivative and class litigation, multiple attorneys volunteer to serve as counsel for the corporation or class by filing separate actions. The court consolidates the separate actions, allowing all attorneys to participate in the consolidated action. As a result, Professor Coffee argues, the individual attorney lacks a sufficient incentive to invest time and money in developing a derivative or class claim because he cannot exclude other attorneys from the action and therefore cannot be assured of a sufficiently large fee. Coffee, supra note 111 , at 50-56; Coffee, supra note 91, at 233.

131. See FED. R. Civ. P. 23.

132. The attorneys ineligible to receive compensation from the fund could make private arrangements with lead counsel to perform work on the case, but lead counsel would be under no obligation to make any arrangements. 
who are interested in the derivative proceedings but no longer have an economic inducement to intervene or to file parallel suits may decide to participate in the proceedings as objectors if sufficient financial rewards are available to them for doing so. ${ }^{133}$

By discouraging intervention while encouraging objection, the corporation's interests will be better safeguarded from the conflicts of interest intrinsic to shareholder derivative litigation. Because the objector's counsel has not participated in the settlement negotiations and thus has had no opportunity to improve his personal financial position at the expense of the corporation's interests, he will be able to investigate and evaluate the fairness of the corporation's net recovery from a far more neutral vantage. ${ }^{34}$ Promoting the participation of the adversary objector can be accomplished most readily by providing objecting shareholders with broad procedural and discovery rights and by offering them a financial inducement to investigate the proposed settlement. Implementing these changes not only furthers the corporation's interests at a relatively low cost, but also protects the integrity of the approval process.

\section{Returning to a Percentage-of-the-Recovery Fee System}

The third solution to the conflict of interest problems in derivative settlements is to alter the method for calculating the plaintiff's attorney fees.

Although the rule that the corporation must bear the reasonable attorney fees incurred by the shareholder in litigating a derivative claim is firmly established, ${ }^{135}$ the appropriate method for calculating the amount of these fees is far from settled. Courts have adopted three basic approaches for calculating attorney fees or have applied, either explicitly or implicitly, hybrid methods which incorporate aspects of two or more approaches. After discussing these three methods and the approach in recent A.L.I. proposals, ${ }^{136}$ this note proposes a percentage-of-the-recovery method of fee calculation ${ }^{137}$ with modifications that respond to the judicial and scholarly criticism of that method.

133. See supra notes $140-41$ and accompanying text.

134. The corporation's net recovery is the gross settlement amount less plaintiffs counsel fees and indemnification expenses.

135. Mills v. Electric Auto-Lite Co., 396 U.S. 375, 392 (1970); see also Alyeska Pipeline Serv. Co. v. Wilderness Soc'y, 421 U.S. 240, 247 (1975).

The pubic policy underlying derivative suit litigation is founded on two objectives. The first is therapeutic-maintaining the economic health of the corporate system through shareholder oversight of management. Hornstein, Legal Therapeutics: The "Salvage" Factor in Counsel Fee Awards, 69 HaRv. L. Rev. 658, 663 (1956). The second is prophylactic-providing a deterrent to future wrongdoing by corporate managers.

136. Corporate Governance (June 1985), supra note $88, \S 7.17$; Corporate Governance (Nov. 1984), supra note $88, \S 7.18$.

137. See infra notes $194-201$ and accompanying text. 
1. Methods of Fee Calculation. Courts have used three methods to determine the plaintiff's counsel fees in derivative suit settlements. ${ }^{138}$ The first of these methods, the percentage-of-the-recovery approach, enjoyed general acceptance until the late 1960's. Under this approach, the plaintiff's counsel is compensated on the basis of the benefit he confers upon the corporation as measured by the total recovery obtained in the settlement. ${ }^{139}$ Calculation of fees is straightforward: the attorney receives a judicially determined percentage of the corporate recovery. Courts have exercised their discretion in setting the percentage figure, but attorneys generally receive between twenty and thirty percent of the corporate recovery. ${ }^{140}$

The second method of fee calculation is more difficult to define. This method will be referred to as the "multifactor" approach, although this term is not one courts use to describe it. Under the multifactor approach, courts first identify a number of factors which are considered significant in determining the amount of attorney fees to which the plaintiff is entitled and then cryptically announce that amount. ${ }^{141}$ In one case, the Fifth Circuit considered twelve factors to be significant:

1. time and labor required;

2. novelty and difficulty of questions;

3. skill requisite to perform the legal service properly;

4. preclusion of other employment;

5. customary fees for similar work in the community;

6. whether the fee is fixed or contingent;

7. time limitations imposed by the client or circumstances;

8. amount involved and results obtained;

9. experience, reputation, and ability of the attorney;

10. the "undesirability" of the case; and

11. the nature and length of the professional relationship with the client;

12. awards in similar cases. ${ }^{142}$

138. Often, while purportedly following one method of fee computation, courts consider factors or apply formulae from other methods.

139. Other factors such as the complexity of the case, the skill of the attorney, and the risk of litigation have been identified as relevant but not of primary importance. Milstein v. Werner, 58 F.R.D. 544, 549-50 (S.D.N.Y. 1973); see also Neuman v. Electronic Specialty Co., 1970-71 Fed. SEC. L. REP. (CCH) ๆ 92,955, at 90,516 (Jan. 28, 1971).

140. See, e.g., Pergament v. Kaiser-Frazer Corp., 224 F.2d 80, 82 (6th Cir. 1955); Milstein v. Werner, 58 F.R.D. 544, 550 (S.D.N.Y. 1973).

A lower percentage of the total recovery often was awarded where the recovery exceeded one million dollars. E.g., Winkelman v. General Motors Corp., 48 F. Supp. 504, 506 (S.D.N.Y. 1942), affd sub nom. Singer v. General Motors Corp., 136 F.2d (2d Cir. 1943); Mann v. Superior Court, 53 Cal. App. 2d 272, 274, 127 P.2d 970, 972 (1942); see Cole, Counsel Fees in Stockholders' Derivative ana Class Actions-Hornstein Revisited, 6 U. Rich. L. Rev. 259, 281 (1972); Mowrey, Attorney Fees in Securitie: Class Action and Derivative Suits, 3 J. Corp. L. 267, 276 (1978).

141. See, e.g., Johnson v. Georgia Highway Express, Inc., 488 F.2d 714, 717-20 (5th Cir. 1974) Angoff v. Goldfine, 270 F.2d 185, 185-89 (Ist Cir. 1959).

142. Johnson v. Georgia Highway Express, Inc., 488 F.2d 714, 717-20 (5th Cir. 1974). Bott Congress and the Supreme Court have cited Johnson with approval in a nonderivative suit context, $S$ 
The third approach, which is known as the "lodestar" formula, has been approved by at least seven federal courts of appeal. ${ }^{143}$ Unlike its predecessors, the lodestar formula focuses on the hours spent by the attorney on the case. The court initially determines the amount to which the attorney would be entitled on the basis of an hourly rate of compensation applied to the number of hours worked-this amount is the "lodestar" of the court's fee determination. ${ }^{144}$ Next, the court takes account of at least two other factors: the "contingent nature of success" 145 (the risk of litigation) and the quality of the attorney's work. ${ }^{146}$ This second step determines a percentage amount by which the lodestar figure should be increased or possibly decreased. ${ }^{147}$ The total fee awarded to the plaintiff's counsel is the sum of the lodestar amount and any percentage bonus which the court has assessed on the basis of the secondary factors. ${ }^{148}$

The earlier of the two A.L.I. proposals considered here adopts the lodestar approach with two modifications. The A.L.I.'s November, 1984 proposal permits the court to consider factors in addition to the risk of litigation and the quality of the attorney's work in computing the contingency bonus. The court may award a bonus based on other "equitable factors" including the impact of deferred attorney fee payment and the effect of the award on the willingness of other attorneys to bring similar actions. ${ }^{149} \mathrm{~A}$ more recent draft has deleted reference to either a lodestar calculation or equitable factors in the black letter rule. Both A.L.I. proposals authorize a reduction of the attorney fee if it exceeds a reasonable percentage of the total recovery, including the value of nonpecuniary settlement terms. ${ }^{150}$ This equitable cap on the attorney's hours-plus-bonus fee represents a

ReP. No. 1011, 94th Cong., 2d Sess. 6 (1976); H.R. ReP. No. 1558, 94 th Cong., 2d Sess. 8 (1976); Blum v. Stenson, $104 \mathrm{~S}$. Ct. 1541,1546 (1984).

143. Leubsdorf, The Contingency Factor in Attorney Fee Awards, 90 YALE L.J. 473, 473 n.1 (1981); Corporate Governance (Nov. 1984), supra note $88, \$ 7.18$ comment $\mathrm{c}$.

For the origins of the lodestar formula, see Lindy Bros. Builders, Inc. v. American Radiator \& Standard Sanitary Corp., 487 F.2d 161 (3d Cir. 1973).

144. Lindy Bros. Builders, Inc. v. American Radiator \& Standard Sanitary Corp., 487 F.2d 161, 167-68 (3d Cir. 1973).

145. Id. at 168; Frankenstein v. McCrory Corp., 425 F. Supp. 762, 767 (S.D.N.Y. 1977) (the greater the probability of plaintiff's success at trial or by settlement the less the fee award should include a multiple of the hourly rate).

146. In considering the quality of the attorney's work, the court considers the complexity and novelty of the issues in the case, the quality of the work the judge has observed, and the amount of recovery obtained. Lindy Bros. Builders, Inc. v. American Radiator \& Standard Sanitary Corp., 487 F.2d 161, 168 (3d Cir. 1973).

147. Id.; see City of Detroit v. Grinnell Corp., 495 F.2d 448, 471 (2d Cir. 1974); Levenson v. Overseas Shipbuilding Group, Inc., 84 F.R.D. 354, 360 (S.D.N.Y. 1979); Williams v. Schatz Mfg. Co., 449 F. Supp. 147, 152-53 (S.D.N.Y. 1977).

148. Lindy Bros. Builders, Inc. v. American Radiator \& Standard Sanitary Corp., 487 F.2d 161. 168 (3d Cir. 1973); City of Detroit v. Grinnell Corp., 495 F.2d 448, 471 (2d Cir. 1974); Barnett v. Pritzger, 73 F.R.D. 430,433 (S.D.N.Y. 1977).

149. Corporate Governance (Nov. 1984), supra note $88, \S 7.18$ comment e. The delay in payment is also considered in Corporate GoverNANCE (June 1985), supra note 88, § 7.17, Reporter's Note 4 , at 239-40.

150. See, e.g., Corporate Governance (June 1985), supra note $88, \S 7.17$ comment d. 
compromise between a pure percentage and a pure hourly formula and, as the proposals suggest, is consistent with what courts do in practice. ${ }^{151}$

2. Evaluation and Comparison. The efficacy of the various methods of fee calculation can be evaluated by asking three questions: (1) Does the method intuitively produce "fair" results? (2) Is the method practical so that it is reasonably easy for courts to apply? and (3) What incentives for desirable and undesirable behavior does the method provide?

a. "Fairness" of result. Irrespective of the method used, courts agree that attorney fee awards in derivative litigation should be adequate to encourage efforts to monitor the actions of corporate management, ${ }^{152}$ but should not be so great as to encourage frivolous suits, ${ }^{153}$ or result in a "windfall" to the shareholder's attorney. ${ }^{154}$ The percentage-of-the-recovery approach evoked concern among courts because, in settlements involving substantial recoveries, attorneys could receive extremely large fees without devoting much time or effort to the case. By giving the court greater discretion, as the multifactor approach does, or by computing compensation on the basis of hours expended, as the lodestar formula does, the court could achieve greater congruence between the fee award and the attorney's actual expenditure of time and energy on the case. ${ }^{155}$

Although more sensitive to the effort expended by the attorney, the newer formulae introduce new inequities. Inequity under the multifactor approach derives from the lack of clarity and specificity regarding the factors which are most and least significant. ${ }^{156}$ Under the multifactor approach, the factors considered in a fee determination are merely identified seriatim without any significant discussion of the court's reasoning process. As a consequence, the guidelines for litigants and their attorneys are no more meaningful than a general standard of reasonableness. ${ }^{157}$ Though windfall fee awards might be avoided under the multifactor approach, the downside of this approach is the loss of predictability and consistency in fee awards. The court's ad hoc determination of equitable compensation conveys little information to future litigants and their counsel regarding the kinds of activity that will be rewarded and those that will not.

151. Id. $\$ 7.17$, comment a.

152. Angoff v. Goldfine, 270 F.2d 185, 192 (1st Cir. 1959); Milstein v. Werner, 58 F.R.D. 544, 549 (S.D.N.Y. 1973); Steinberg v. Hardy, 93 F. Supp. 873, 873 (D. Conn. 1950).

153. Milstein v. Werner, 58 F.R.D. 544, 549 (S.D.N.Y. 1973); Steinberg v. Hardy, 93 F. Supp. 873, 873 (D. Conn. 1950).

154. City of Detroit v. Grinnell Corp., 495 F.2d 448, 469 (2d Cir. 1974); Weinberg v. Coastal States Gas Corp., 1982 Fed. Sec. L. REP. (CCH) I 98,716, at 93,589 (S.D.N.Y. 1982); see Blum v. Stenson, 465 U.S. 886 (1984).

155. Coffee, supra note 91 , at 241.

156. See Mowrey, supra note 140, at 304-05.

157. See Johnson v. Georgia Highway Express, Inc., 488 F.2d 714, 717-19 (5th Cir. 1974); Angoff v. Goldfine, 270 F.2d 185, 189 (I st Cir. 1959); Clark v. Cameron-Brown Co., [Jan.-June] SEC. REG. \& L. REP. (BNA) No. 605, at A-17, A-18 (April 16, 1981). 
Inequity under the lodestar approach exists because attorneys are paid for the length of time spent on a case regardless of how productive they are during that time. In short, "inexperience, inefficiency, even incompetence ... [are] rewarded." 158 To some extent, this defect is avoided by the "intensified scrutiny" courts are expected to exercise under the lodestar method. ${ }^{159}$ But because courts see little of the attorney's preparation and performance in cases settled prior to trial, inefficiency is difficult to detect. Consequently, the attorney's hour-based fee is not discounted for unproductive time spent on the case.

By introducing a "reasonable percentage of the total recovery" as a ceiling on attorney fees, both A.L.I. proposals considered here eliminate the worst abuses of the lodestar method. As the A.L.I. drafts concede, however, courts often informally impose a similar ceiling even in the absence of specific authorization. ${ }^{160}$ The earlier A.L.I. draft explicitly enumerates a number of factors courts may look at in determining whether an attorney is entitled to a contingency bonus. Four factors are specifically identified, although the court is allowed to consider other "equitable factors." 161 . The relative weight of each of these factors is apparently left to the court since the draft does not attach any values to the factors it identifies. Accordingly, the earlier proposal expands the scope of judicial discretion so that, like the multifactor approach, it reduces the predictability and consistency of the lodestar formula. The exercise of judicial discretion, while explicitly contemplated in the later A.L.I. draft concerning assessment of attorney fees, is no longer tied to concrete guidelines in the black letter rule.

b. Ease of application. Obviously, if a method of calculation is theoretically sound but impossible or at least very difficult to implement, it has little value. While none of the fee calculation approaches outlined above is impossible to apply, the ease with which they can be implemented varies significantly.

The multifactor approach seems to be the easiest method to apply because the court can consider practically anything it wants. ${ }^{162}$ Once the court identifies the factors considered relevant to the fee determination, it may avoid a rigorous analysis of the extent to which each factor affects the ultimate dollar figure the attorney receives. ${ }^{163}$ Even more fundamental, the court need not identify its method of analysis. As a result, courts using the multifactor

158. "[W]hen hours become a criterion, economy of time may cease to be a virtue. Inexperience, inefficiency, even incompetence will be rewarded. Expeditious termination of litigation will be discouraged-to the great cost of all concerned, including the state." Hornstein, supra note 135 , at $660-61$.

159. City of Detroit v. Grinnell Corp., 495 F.2d 448, 471 (2d Cir. 1974).

160. See, e.g., Corporate Governance (June 1985), supra note 88 , $\$ 7.17$ comment a.

161. Corporate Governance (Nov. 1984), supra note 88, § 7.18(a)(i).

162. See Johnson v. Georgia Highway Express, Inc., 488 F.2d 714, 717-19 (5th Cir. 1974); Angoff v. Goldfine, 270 F.2d 185, 189 (1st Cir. 1959); Clark v. Cameron-Brown Co., [Jan.-June] SeC. ReG. \& L. REP. (BNA) No. 605, at A-17, A-18 (Apr. 16, 1981).

163. See supra notes $156-57$ and accompanying text. 
method have not indicated if they begin with some starting point and then adjust the fee upward or downward to take account of the various factors, or if each factor is quantified so that the sum of these amounts becomes the attorney's fee. In fact, courts applying the multifactor approach may have sought to avoid appellate criticism by obscuring exactly what their method of analysis was.

The multifactor method is easy to use for several other reasons. Nonpecuniary settlement terms ${ }^{164}$ present little difficulty to a court applying a multifactor method because the attorney's fee is not directly tied to the value of the settlement he obtains for the corporation. If the size of the recovery is a factor the court considers, less emphasis may be placed on that factor when the settlement consists primarily of nonpecuniary benefits. Finally, the court is not overwhelmed with papers documenting the attorney's time because the fee is not calculated on the basis of the number of hours the attorney worked. ${ }^{165}$

In contrast to the multifactor method, the percentage-of-the-recovery approach works easily only when the settlement is entirely monetary. In that event, the court simply multiplies the total recovery by the determined percentage. Some courts have applied a flat twenty percent formula to the settlement value, ${ }^{166}$ while others have adjusted the percentage because the settlement is extremely large or for other reasons. ${ }^{167}$ Even when the court adjusts the percentage, the application of the formula to the settlement fund is straightforward and involves little documentation by the attorney and little of the court's time.

Applying a percentage formula becomes more difficult when the settlement includes nonpecuniary terms. Because such terms by definition have no precise monetary value, courts have not used a percentage formula, opting instead to add a "reasonable" amount to the attorney's percentage of the cash recovery to compensate him for obtaining the nonpecuniary settlement terms. ${ }^{168}$

The hours-plus-bonus approach of the lodestar method solves the problem of nonpecuniary settlement terms, but it does so through the introduction of complexity and the consumption of substantially more court time. Courts must carefully examine the attorney's documentation of time

164. A reorganization of the corporation's board of directors, the appointment of a new committee to study internal procedures, and additional disclosure of corporate financial information are examples of nonpecuniary settlement terms.

165. Both the amount of recovery and the number of hours worked may, however, be factors the court will consider. See Wolf v. Frank, 555 F.2d 1213, 1218 (5th Cir. 1977); Kiser v. Miller, 364 F. Supp. 1311,1315 (D.D.C. 1973), modified on other grounds sub nom. Kiser v. Illuge, 517 F.2d 1237 (D.C. Cir. 1974).

166. Pergament v. Kaiser-Frazer Corp., 224 F.2d 80, 82 (6th Cir. 1955); Neuman v. Electronic Specialty Co., 1970-71 FED. SEc. L. ReP. (CCH) I 92,955, at 90,519 (Jan. 28, 1971 ).

167. Milstein v. Werner, 58 F.R.D. 544, $551-52$ (S.D.N.Y. 1973); Newmark v. RKO Gen., Inc., 332 F. Supp. 161, 163 (S.D.N.Y. 1971); Winkelman v. General Motors Corp., 48 F. Supp. 504, 506 (S.D.N.Y. 1942), aff sub nom. Singer v. General Motors Corp., 136 F.2d 905 (2d Cir. 1943).

168. Pergament v. Kaiser-Frazer Corp., 224 F.2d 80, 84 (6th Cir. 1955). 
spent on the case in order to discover any "padding" of the attorney's hours or other time recorded for which he should only be partially-if at allcompensated. ${ }^{169}$ Courts must also determine the hourly rate which should be used to compute the attorney's lodestar figure. ${ }^{170}$

The judicial task is further complicated by the contingency bonus aspect of compensation under a lodestar approach. In considering the risk involved in bringing suit, courts must make a difficult retrospective assessment of what the successful plaintiff's chance of success appeared to be before the litigation began. ${ }^{171}$ Manifestly, this assessment is extraordinarily difficult to makesomewhat like predicting the outcome of an election after the results are in.

Implementation of the first A.L.I. proposal differs very little from that of the basic lodestar approach. Although courts have several more factors to evaluate, the fundamental analytical process remains the same. Courts under the second A.L.I. proposal could opt to use this approach as well. The new "reasonable percentage of recovery" ceiling requires the court to question whether the attorney's allowance, computed on an hourly basis, exceeds a "reasonable percentage" of the settlement amount-but there are indications that courts apply a similar "reasonableness" standard even in the absence of an explicit ceiling. ${ }^{172}$

c. Incentives. Legal commentary in the area of attorney fee computation has recently focused on the incentives that fee computation formulae provide for desirable and undesirable litigation behavior. ${ }^{173}$ Although the commentators who have ventured into this area look at different aspects of attorney fee formulae and reach somewhat different conclusions with respect to remedial measures, they have a common enemy in the reactive nature of current attorney fee awards. ${ }^{174}$ Present compensation methods treat attorneys' litigation behavior as fixed and then attempt to calculate a reasonable fee allowance for that behavior. According to the commentators, if compensation formulae instead approached attorneys' behavior as responsive to the method of calculating their fees, the formulae should

169. Noncompensable time includes, but is not limited to, hours spent duplicating the work of other attorneys, hours spent on irrelevant matters, and, in some jurisdictions, hours spent preparing the fee application. See Williams v. Schatz Mfg. Co., 449 F. Supp. 147, $151-52$ (S.D.N.Y. 1977); In re Penn Central Sec. Litig., 416 F. Supp. 907, 918 (E.D. Pa. 1976), rev'd on other grounds, 560 F.2d 1138 (3d Cir. 1977); Miller v. Mackay Int', Inc., 70 F.R.D. 533, 537 (S.D. Fla. 1976).

170. There is considerable controversy as to whether the attorney should be compensated on the basis of his own hourly rate or the general rate in the community and, for either rate, which noncontingent hourly rate should be considered comparable to the derivative suit rate. See Blum v. Stenson, 465 U.S. 886 (1984); Boggess v. Hogan, 410 F. Supp. 443, 447 (N.D. Ill. 1976); Entin v. Barg, 412 F. Supp. 508, 517 (E.D. Pa. 1976); Green v. Wolf Corp., 69 F.R.D. 568, 572 (S.D.N.Y. 1976).

171. Leubsdorf, supra note 143 , at 486 .

172. Mowrey, supra note 140, at 276; see, e.g., Swanson v. American Consumer Indus., Inc., 517 F.2d 555, 563 (7th Cir. 1976); Weisberg v. Coastal States Gas Corp., 1982 Fed. SEC. L. REP. (CCH) q 98,716 , at $93,589(1982)$.

173. See Clermont \& Currivan, supra note 91; Coffee, supra note 91; Coffee, supra note 111; Leubsdorf, supra note 143; Mowrey, supra note 140.

174. Sep Clermont \& Currivan, supra note 91; Coffee, supra note 91; Leubsdorf, supra note 143. 
attempt to provide incentives for desirable kinds of litigation behavior and disincentives for undesirable behavior. This section of the note examines the incentives that the three fee computation methods provide.

By obscuring the method of analysis, the multifactor approach also hides the incentives it provides. One discernible incentive, however, results from the lack of predictability and consistency inherent in the nebulous standards of the multifactor approach. Common sense suggests that, if the attorney is unable to predict the amount of fees he will receive should he succeed, he will try to minimize the risk of litigation by bringing a high volume of cases. ${ }^{175}$ Consequently, the attorney is unable to invest much time or effort in any single case and is therefore likely to be satisfied with a relatively low settlement. This incentive creates many poorly handled derivative suits, a significant portion of which are of questionable merit.

The lodestar method of fee computation ${ }^{176}$ produces incentives for both desirable and undesirable conduct by the plaintiff's counsel. On the positive side, the lodestar formula encourages full investigation and negotiation of derivative claims because counsel is compensated for the hours worked.177 Unfortunately, the lodestar method's hour-based compensation also promotes dilatory conduct and duplicative services by the plaintiff's counsel. To the extent the attorney's working time is not completely consumed by equally well-paying cases, the attorney has an economic incentive to conduct extensive discovery, perform lengthy research, and stretch out settlement negotiations in order to maximize the number of hours for which he will be compensated. ${ }^{178}$ The client's economic interest, on the other hand, is served when the attorney works the greatest number of hours which correspond to a positive marginal rate of recovery. ${ }^{179}$

Even more importantly, the attorney has a strong incentive to accept a settlement once he has expended a substantial amount of time on a case in order to avoid the risk of losing in litigation. This incentive may cause the attorney to accept a settlement that his clients would consider insufficient. ${ }^{180}$ Thus, the lodestar method of fee computation provides incentives for litigation conduct in conflict with the client's best interests.

Another incentive created by the hourly fee method is inducement of tacit collusion between the plaintiff's counsel and the defendant. The plaintiff's attorney wants to maximize his fee. The defendant wants to minimize his

175. Coffee, supra note 91 , at 231. The attorney's risk diversification may be analogized to a portfolio investment approach.

176. Because the A.L.I. proposals adopt the basic lodestar approach with relatively minor adjustments, the drafts probably would create incentives similar to those of the "pure" lodestar formula.

177. The lodestar formula thus compares favorably with a percentage approach which tends to encourage premature settlement. See infra notes $185-89$ and accompanying text.

178. Clermont \& Currivan, supra note 91, at 536; Coffee, supra note 91, at 240; Herzel \& Hogan, Plaintiff's Attorney Fees in Derivative and Class Actions, LrTiG., Winter 1979, at 25.

179. The marginal rate of recovery equals the additional settlement recovery generated by the last hour worked by the attorney.

180. See Coffee, supra note 111 , at 36 . 
liability. Both parties can obtain what they want by holding a settlement agreement for several months while the plaintiff's attorney expends sufficient time to justify a substantial fee under the lodestar formula. In exchange for this delay in presenting the settlement to the court, the attorney will be amenable to the defendant's offer of a smaller settlement amount. ${ }^{181}$ The defendant's counsel also has no reason to be dissatisfied because, through procrastination, he can charge his own client for the additional time he spends. Put succinctly, a time-based formula "provides the adversaries with a method by which they can assure themselves that the desired fee will be awarded if the settlement is approved." 182

Finally, the lodestar formula also has been criticized for providing an incentive to initiate weak lawsuits. ${ }^{183}$ Because the contingency bonus increases as the risk of litigation becomes greater, attorneys have an economic inducement to bring riskier-and that often means weaker-cases. ${ }^{184}$ This is the very kind of behavior that courts do not want to encourage.

A percentage formula, like the lodestar formula, rewards both desirable and undesirable litigation behavior, but its incentives are precisely opposite those provided by the lodestar formula. The strongest criticism of a percentage approach is that it encourages premature settlements which are not in the best interest of the corporation. ${ }^{185} \mathrm{~A}$ percentage formula encourages a premature settlement since an attorney will only work the number of hours for which his marginal rate of compensation ${ }^{186}$ is equal to his opportunity cost, ${ }^{187}$ while the client's economic interests are best served if the attorney works as many hours as possible so long as the marginal rate of recovery ${ }^{188}$ is still positive. ${ }^{189}$ Thus, the attorney may be satisfied with a small settlement amount if he can obtain that amount by expending little time and effort. On the other hand, the client's interests are maximized by holding out for a larger settlement regardless of how much time his attorney has to spend to get it.

One commentator also has criticized the percentage method of fee calculation for exacerbating the tendency of attorneys to "piggyback" on government investigations and prosecutions. ${ }^{190}$ Because the research costs necessary to investigate and develop new derivative cases are considerably lower when the SEC has initiated proceedings or conducted an investigation of the same activities, attorneys tend to initiate suits which can take advantage of government proceedings, and are far less likely to sue when the

181. Coffee, supra note 91 , at 247.

182. Id.

183. Leubsdorf, supra note 143 , at 474.

184. Id.

185. See Clermont \& Currivan, supra note 91, at 543-46; Coffee, supra note 91, at 268.

186. The marginal rate of compensation equals the additional compensation generated by the last hour the attorney worked.

187. Opportunity cost is the income the attorney could have earned by working on other cases.

188. See supra note 179 .

189. Clermont \& Currivan, supra note 91 , at 543-46.

190. Coffee, supra note 91 , at 249. 
government has not taken the lead. ${ }^{191}$ As a result, private actions tend to duplicate rather than supplement public enforcement efforts. ${ }^{192}$ The attorney's incentive to press only those claims for which he can obtain information collected by the SEC is greatest under a percentage method of fee calculation because only the attorney's results are compensated, not the time he spends on the case.

Nevertheless, the percentage-of-the-recovery formula at least partially aligns the attorney's own economic interests with those of his client. The higher the settlement obtained, the higher the attorney's fee allowance will be; in effect, the attorney and client become "partners."193 The attorney thus has no incentive to compromise his client's cause of action to obtain higher fees for himself. The attorney also has no incentive to delay the settlement process since his fees are the same regardless of when the settlement agreement is submitted to the court for its approval. By partially aligning the attorney's interest with those of his client, a percentage-of-the-recovery method of fee computation largely avoids the conflict of interest problem inherent in the lodestar method's hour-based formula.

3. A Fee Computation Proposal. Based on the strengths of the percentage-ofthe-recovery approach-its predictability, its simplicity, and its (at least partial) alignment of attorney and client interests-this note proposes a needed return to that method with only minor modifications. In addition to its practical strengths, the percentage method best effectuates the objectives of derivative litigation. Our proposal could be instituted either by courts or by legislatures and includes the following basic provisions:

The court, upon approving the settlement of a derivative suit, should award the shareholder's attorney a presumptive percentage of the corporation's gross recovery. In determining the gross recovery, the court should expressly determine the value of any nonpecuniary settlement terms and include their value in the gross recovery. The presumptive percentage should be awarded except where:

(1) the suit and its settlement were unusually beneficial to the corporation or the public and this unusual benefit is not fully reflected in the gross recovery; ${ }^{194}$

(2) the suit followed and took advantage of information obtained in a government investigation or prosecution; or

191. Id.

192. See, e.g., Jamison v. Butcher \& Sherrerd, 68 F.R.D. 479 (E.D. Pa. 1975).

193. See Clermont \& Currivan, supra note 91 , at 543-46.

194. Because the presumptive percentage is keyed to the corporation's gross recovery, it is not sensitive to indemnification amounts paid to the individual defendants by the corporation. Although such amounts clearly affect the net benefit to the corporation, taking them into account would result in diminishing the plaintiff's attorney fee percentage as the settlement amount becomes larger. Aside from the obvious incongruity which would result, the plaintiff's attorney could not tailor his behavior (in bringing derivative claims) in response to indemnification amounts because of the extreme difficulty in predicting these amounts. In addition, a corporation could use generous indemnification plans to ward off derivative suits. 
(3) awarding the presumptive percentage would result in unreasonably high compensation for the attorney in relation to the work he performed.

The attorney's percentage of the gross recovery should be increased under circumstance ( 1 ) and decreased under circumstances (2) and (3) by an amount which the court determines is appropriate.

The analysis under the proposed formula begins with an assumption that a predetermined percentage of the value of the derivative settlement (perhaps twenty to twenty-five percent) is a reasonable and appropriate fee allowance for the plaintiff's attorney under most circumstances. ${ }^{195}$ This assumption is based upon data which indicate that, even when courts apply an hourly fee formula, attorney fee awards generally constitute twenty to thirty percent of the total settlement. ${ }^{196}$ The proposed formula is also based upon the assumption that, although nonpecuniary settlement terms present greater difficulty than a cash settlement, the court can reach a reasonable estimation of the dollar value of the nonpecuniary terms and include that estimated value in the gross recovery upon which the percentage fee is calculated. ${ }^{197}$

The proposal does acknowledge, however, that courts will be faced with settlements for which a twenty to twenty-five percent fee award would be plainly inequitable. ${ }^{198}$ The three situations in which a percentage formula may result in unreasonable fees are: (1) where the derivative suit produced a benefit (in particular, the deterrence of corporate mismanagement) which is not completely reflected in the monetary value of the settlement; (2) where the attorney expended relatively little time or effort in investigating and developing his case because he substantially relied upon information produced by a governmental investigation or prosecution; ${ }^{199}$ and (3) where applying the standard percentage formula would result in a "windfall" to the attorney in relation to the work he performed on the case. ${ }^{200}$ Under these

195. See generally Hornstein, supra note 40.

196. See Coffee, supra note 91, at 241 n.63; Mowrey, supra note 140, at 337; Corporate Governance (June 1985), supra note $88, \S 7.17$ comment c.

197. Depending on the willingness of courts to attribute high values to nonpecuniary settlement terms, the presumptive percentage approach may produce a bias toward or against nonpecuniary relief. Some commentators have argued that present methods of fee calculation, particularly the lodestar method, induce agreements for nonpecuniary relief at the expense of pecuniary relief. Because the presumptive percentage method outlined here requires the court to place an explicit dollar value on the nonpecuniary relief, it at least necessitates a realistic appraisal by the court of the benefits produced by that relief and thus may halt the recent trend toward "therapeutic" relief. See Coffee, supra note 91, at 267; Coffee, supra note 111 , at 40 .

198. An additional and important constraint on the attorney's fee is the court's authority to disapprove the settlement itself. If the court, for example, believes the shareholder's claim was compromised prematurely, it can refuse to sanction the proposed settlement.

199. If the court believes the attorney was able to save considerable time by taking advantage of a prior government proceeding or investigation very similar to the derivative claim, the court would adjust the attorney's percent downward to, perhaps, $15 \%$.

200. The court thus could reduce the attorney's compensation if it believed the settlement was essentially fair to the sharcholders but was concerned that the attorney settled too soon or was less diligent than was in the client's best interest. 
circumstances, courts should exercise their discretion to adjust the percentage of recovery upward or downward.

Returning to a percentage-of-the-recovery approach would ameliorate two fundamental problems of derivative suit settlements. By greatly simplifying the procedure courts use to determine counsel's compensation, the percentage-of-the-recovery approach reduces the burden on the courts ${ }^{201}$ and increases the predictability and consistency of fee awards. The percentage formula would also realign the attorney's economic interest to coincide with that of the corporation. A modified percentage-of-the-recovery formula removes the incentive for collusion between counsel for the parties, thereby reinforcing a ban on the contemporaneous discussion of the settlement and the plaintiff's attorney fees. While the reinstitution of a percentage fee formula may tend to encourage the premature settlement of claims, the court's authority to reject the settlement provides an effective restraint against such undesirable behavior.

\section{IV}

\section{Conclusion}

Two broad themes underlie the issues explored in this note. The first is that the shareholders' legal representative must have objectives similar to those of his clients if the derivative action is to be an effective means of remedying and preventing abuses by corporate management. Ensuring that the shareholders and their counsel pursue similar goals is most effectively achieved by changing the method by which attorney fees are awarded to provide counsel with incentives to behave in a manner consistent with the corporation's best interests. More specifically, this note advocates three changes in the method of computing attorney fees. First, the method should emphasize the attorney's results rather than the amount of time he devoted to the case. Second, courts should be reluctant to award fees on the basis of nonpecuniary settlement terms unless some dollar value can be reasonably attached to those terms. Third, the attorney should be protected from efforts by intervenors' counsel to obtain a share of the fee award by limiting the number of plaintiff's attorneys eligible for court-awarded fees.

The second underlying theme is that, while court approval of settlements is an essential aspect of derivative litigation, its limitations cannot be overlooked. When both plaintiff and defendant advocate the same positionapproval of their negotiated settlement-the court's task of assuring the fairness of the settlement becomes an extremely difficult one. Prohibiting contemporaneous negotiation of the settlement amount and attorney fees and encouraging objectors who present the court with independent information permit the court to examine the settlement and thereby assure its fairness without requiring an exhaustive investigation into every aspect of the

201. See supra notes 169-71 and accompanying text. "A request for attorney's fees should not result in a second major litigation." Hensley v. Eckerhart, 461 U.S. 424, 427 (1983). 
settlement. In addition, changing the method of computing attorney fees from an hour-based formula to a percentage-of-the-recovery approach relieves the court of its virtually impossible duty to monitor attorneys' time and performance.

The peculiar consequences and concerns involved in shareholder derivative suit settlements explored in this note are the direct result of the unique relationships among participants in this type of litigation. If the derivative suit is to continue (or even attempt) to be "the chief regulator of corporate management," courts and commentators must focus on how these unique relationships can be reshaped to promote the best interests of the corporation. 
